\title{
Complex Genital System of a Haplogyne Spider (Arachnida, Araneae, Tetrablemmidae) Indicates Internal Fertilization and Full Female Control Over Transferred Sperm
}

\author{
Matthias Burger, ${ }^{1 *}$ Peter Michalik, ${ }^{2}$ Werner Graber, ${ }^{3}$ Alain Jacob, ${ }^{4}$ Wolfgang Nentwig, ${ }^{5}$ and \\ Christian Kropf ${ }^{1}$ \\ ${ }^{1}$ Natural History Museum, Department of Invertebrates, CH-3005 Bern, Switzerland \\ ${ }^{2}$ Zoological Institute and Museum, Ernst-Moritz-Arndt-University, D-17489 Greifswald, Germany \\ ${ }^{3}$ Institute of Anatomy, University of Bern, CH-3000 Bern, Switzerland \\ ${ }^{4}$ Zoological Institute of the University of Bern, Conservation Biology, CH-3012 Bern, Switzerland and Natural \\ History Museum, CH-3005 Bern, Switzerland \\ ${ }^{5}$ Zoological Institute of the University of Bern, Community Ecology, CH-3012 Bern, Switzerland
}

ABSTRACT The female genital organs of the tetrablemmid Indicoblemma lannaianum are astonishingly complex. The copulatory orifice lies anterior to the opening of the uterus externus and leads into a narrow insertion duct that ends in a genital cavity. The genital cavity continues laterally in paired tube-like copulatory ducts, which lead into paired, large, saclike receptacula. Each receptaculum has a sclerotized pore plate with associated gland cells. Paired small fertilization ducts originate in the receptacula and take their curved course inside the copulatory ducts. The fertilization ducts end in slitlike openings in the sclerotized posterior walls of the copulatory ducts. Huge masses of secretions forming large balls are detectable in the female receptacula. An important function of these secretory balls seems to be the encapsulation of spermatozoa in discrete packages in order to avoid the mixing of sperm from different males. In this way, sperm competition may be completely prevented or at least severely limited. Females seem to have full control over transferred sperm and be able to express preference for spermatozoa of certain males. The lumen of the sperm containing secretory balls is connected with the fertilization duct. Activated spermatozoa are only found in the uterus internus of females, which is an indication of internal fertilization. The sperm cells in the uterus internus are characterized by an extensive cytoplasm and an elongated, cone-shaped nucleus. The male genital system of I. lannaianum consists of thick testes and thin convoluted vasa deferentia that open into the wide ductus ejaculatorius. The voluminous globular palpal bulb is filled with seminal fluid consisting of a globular secretion in which only a few spermatozoa are embedded. The spermatozoa are encapsulated by a sheath produced in the genital system. The secretions in females may at least partly consist of male secretions that could be involved in the building of the secretory balls or play a role in sperm activation. The male secretions could also afford nutriments to the spermatozoa. J. Morphol. 267:166-186, 2006. 우 2005 Wiley-Liss, Inc.

KEY WORDS: Haplogynae; Tetrablemmidae; complex genitalia; female control; spermatozoa; secretion

The separation of the araneomorph spiders by Simon (1893) into the two groups Haplogynae and Entelegynae was based on the gross morphology of their external genitalia. Females without an external genital plate (epigynum) having separate openings for the male's sperm-transferring organs and males with comparatively simple palpi were placed in the Haplogynae. The characterization of the two groups was specified by considering the morphology of the internal female genital structures (Wiehle, 1967; Austad, 1984; Coddington and Levi, 1991; Platnick et al., 1991; Uhl, 2002). In haplogyne spiders there should be a single copulatory duct serving for insemination and fertilization. Sperm is stored in paired receptacula which arise directly from the wall of the uterus externus (Wiehle, 1967; Austad, 1984; Uhl, 2002). This kind of receptaculum was classified as "cul-de-sac"-type (Austad, 1984). During oviposition the sperm should leave the same insemination duct again through which it was deposited by the male (Austad, 1984). In entelegynes, there should be separate fertilization ducts leading from the receptacula to the uterus externus (Whiele, 1967). Such receptacula were classified as "conduit"type (Austad, 1984).

The differentiation of "cul-de-sac"- and "conduit"type receptacula led to predictions of sperm priority patterns (Austad, 1984). First male sperm priority was expected for entelegynes (Austad, 1984; Watson, 1991a; Uhl, 2002) and last male sperm priority for haplogynes (Austad, 1984; Kaster and Ja-

\footnotetext{
Contract grant sponsors: Swiss Academy of Sciences (SAS) (travel grant to Thailand); German National Merit Foundation (to P.M.); Swiss National Science Foundation (to A.J.).

*Correspondence to: M. Burger, Natural History Museum, Department of Invertebrates, Bernastrasse 15, CH-3005 Bern, Switzerland. E-mail: burgermatthias@students.unibe.ch
}

Published online 7 November 2005 in

Wiley InterScience (www.interscience.wiley.com)

DOI: 10.1002/jmor.10394 
cob, 1997; West and Toft, 1999; Uhl, 2002; Schaefer and Uhl, 2003). However, general confirmations of these predictions are limited (Eberhard et al., 1993; Uhl, 1994a, 2002; Uhl and Vollrath, 1998; Elgar, 1998). It has to be taken into account that numerous other factors beneath spermathecal morphology can considerably influence sperm priority patterns (Watson, 1991b; Uhl, 2002; DeCarvalho et al., 2004). Males of some species are, e.g., able to manipulate previously deposited sperm by pedipalp movements (Uhl et al., 1995; Huber and Eberhard, 1997; Schäfer and Uhl, 2002). Furthermore, females of different species have developed behavioral, physiological, or morphological mechanisms that favor sperm of certain males against others during or after copulation ("cryptic female choice" in the sense of Eberhard and Cordero, 1995). In this way they are able to influence sperm priority patterns (Higgins, 1989; Eberhard, 1985, 1996, 2004b; Telford and Jennions, 1998; Hellriegel and Ward, 1998; Uhl, 2002; Burger et al., 2003). Sperm competition can be another factor in determining a sperm priority pattern (Brown, 1985; Suter and Parkhill, 1990; Elgar, 1998; Uhl, 1998; Yoward, 1998; Eberhard, 2004b).

However, it is essential to examine the genital system of a species in detail by means of serial sectioning and scanning electron microscopic (SEM) investigations to draw accurate conclusions on the functional morphology of the genitalia (Galis, 1996; Huber, 2002; Burger et al., 2003; Eberhard, 2004a). Functional morphological studies in combination with mating behavioral observations contribute to a better understanding of the complex genital structures in spiders, their role in the context of sexual selection, and their evolution (Eberhard, 1985, 1996, 2004a; Eberhard et al., 1993; Alberti, 1995; Galis, 1996; Hellriegel and Ward, 1998; Uhl, 2002; Alberti and Michalik, 2004; Huber, 2004a; Michalik et al., 2005a).

Studies at least partly following these approaches have been done for entelegynes (Huber 1993, 1994b, 2004a; Uhl and Vollrath, 1998; Uhl and Gunnarsson, 2001; Berendonck and Greven, 2002, 2005; Senglet, 2004) and for haplogynes (Huber, 1994a, 1995, 1997, 1998, 2002, 2004a,b; Uhl, 1994a, 1998, 2000, 2002; Uhl et al., 1995; Huber and Eberhard, 1997; Senglet, 2001; Schäfer and Uhl, 2002; Burger et al., 2003; Michalik et al., 2005a, for a mygalomorph spider with haplogyne genitalia). Especially the Haplogynae are poorly investigated with respect to their genital morphology. Several studies revealed that the internal genital structures of many haplogynes do not correspond to the conventional vulval type described by Whiele (1967): there are, e.g., haplogynes without spatially separated receptacula (Uhl, 1994a; Huber, 2002; Bertani and Silva Junior, 2002 , for a mygalomporph spider with haplogyne genitalia), haplogynes with two different sperm storage organs (Uhl, 2000) or other complex genital structures (Brignoli, 1978; Burger et al., 2003), and haplogynes with entelegyne vulval type (Huber, 1997, 2004b).

The haplogyne spider family Tetrablemmidae is systematically placed as the sister group of the Dysderoidea (Coddington and Levi, 1991; Platnick et al., 1991) and comprises armored spiders with a characteristic pattern of abdominal sclerotization (Shear, 1978; Lehtinen, 1981; Burger, 2005). Most tetrablemmids have a body length of less than $2 \mathrm{~mm}$ and live as soil-dwellers in the litter habitat of tropical rain forests (Brignoli, 1974; Shear, 1978; Deeleman-Reinhold, 1980; Bourne, 1980; Lehtinen, 1981; Burger, 2005). The carapace or the chelicerae of males are often strongly modified (Shear, 1978; Lehtinen, 1981; Schwendinger, 1989, 1994; Burger, 2005).

The present study reports on the tetrablemmid Indicoblemma lannaianum. It describes the complexity of the female and male genital structures by means of serial semithin and ultrathin sections and SEM, and gives a functional explanation of the female reproductive system. Furthermore, notes on the spermatozoa of this species are given.

\section{MATERIALS AND METHODS}

Three of us (M.B., C.K., and A.J.) collected specimens of the tetrablemmid Indicoblemma lannaianum Burger, 2005 from 11-21 July 2003 by sieving the humid leaf litter of the primary evergreen hill forest of Doi Suthep, 1,600 m elevation, near Chiang Mai ( $18^{\circ} 48^{\prime}$ $\mathrm{N}, 98^{\circ} 59^{\prime} \mathrm{E}$ ) in northern Thailand. All spiders were mature when collected, and thus their mating history was unknown. Sixty-four females and 44 males were caught and kept individually in snap-cap glass jars $(3 \mathrm{~cm}$ diameter and $5 \mathrm{~cm}$ height) with ground gypsum, which was moistened every day by one or two drops of water so that the air humidity was almost saturated. The spiders were fed with Collembola (Folsomia candida Willem, 1902).

Fourteen females numbered F1-F14 were mated once in the laboratory and called "single-mated." They were sacrificed using formaldehyde (4\%) according to the following protocol (T) (Table 1): T(A): F1-F3, 15 min after the beginning of copulation (the spiders were separated with a paint brush); $\mathrm{T}(\mathrm{B})$ : F4-F6, immediately after copulation; T(C): F7-F9, $24 \mathrm{~h}$ after copulation; T(D): F10 and F11, 8 days after copulation; T(E): F12-F14, 14 days after copulation. Six females numbered F15-F20 were mated twice in the laboratory and called "double-mated." They were sacrificed using formaldehyde (4\%) according to the following protocol (Table 1): T(F): F15, $30 \mathrm{~min}$, and F16, 22 min after the beginning of the second copulation (the spiders were separated with a paint brush); $\mathrm{T}(\mathrm{G})$ : F17 and F18, immediately after the second copulation; $\mathrm{T}(\mathrm{H}): \mathrm{F} 19$ and F20, $24 \mathrm{~h}$ after the second copulation.

Eight additional females (F21-F28), which were not mated in the laboratory and termed "unknown mating status" (UM in Table 1), and one male were also investigated. Three of these females (F24, F27, F28) were collected by three of us on Doi Suthep. Five females (F21-F23, F25, F26) and the male were collected by Dr. Peter Schwendinger (Geneva Natural History Museum) from 18-20 March 1987 on Doi Angkhang, 920-1,500 $\mathrm{m}$ elevation, $80 \mathrm{~km}$ west of Chiang Rai $\left(19^{\circ} 54^{\prime} \mathrm{N}, 99^{\circ} 50^{\prime} \mathrm{E}\right)$ in northern Thailand.

\section{Light Microscopy}

The opisthosomae of the 20 mated females and the eight females of unknown mating status (F1-F28) and the prosoma and the opisthosoma of the male were dehydrated in ethanol, embedded in LR White Resin (Soft Grade Acrylic, London 
TABLE 1. Schematic drawing of the female genital regions of Indicoblemma lannaianum after first and second copulations

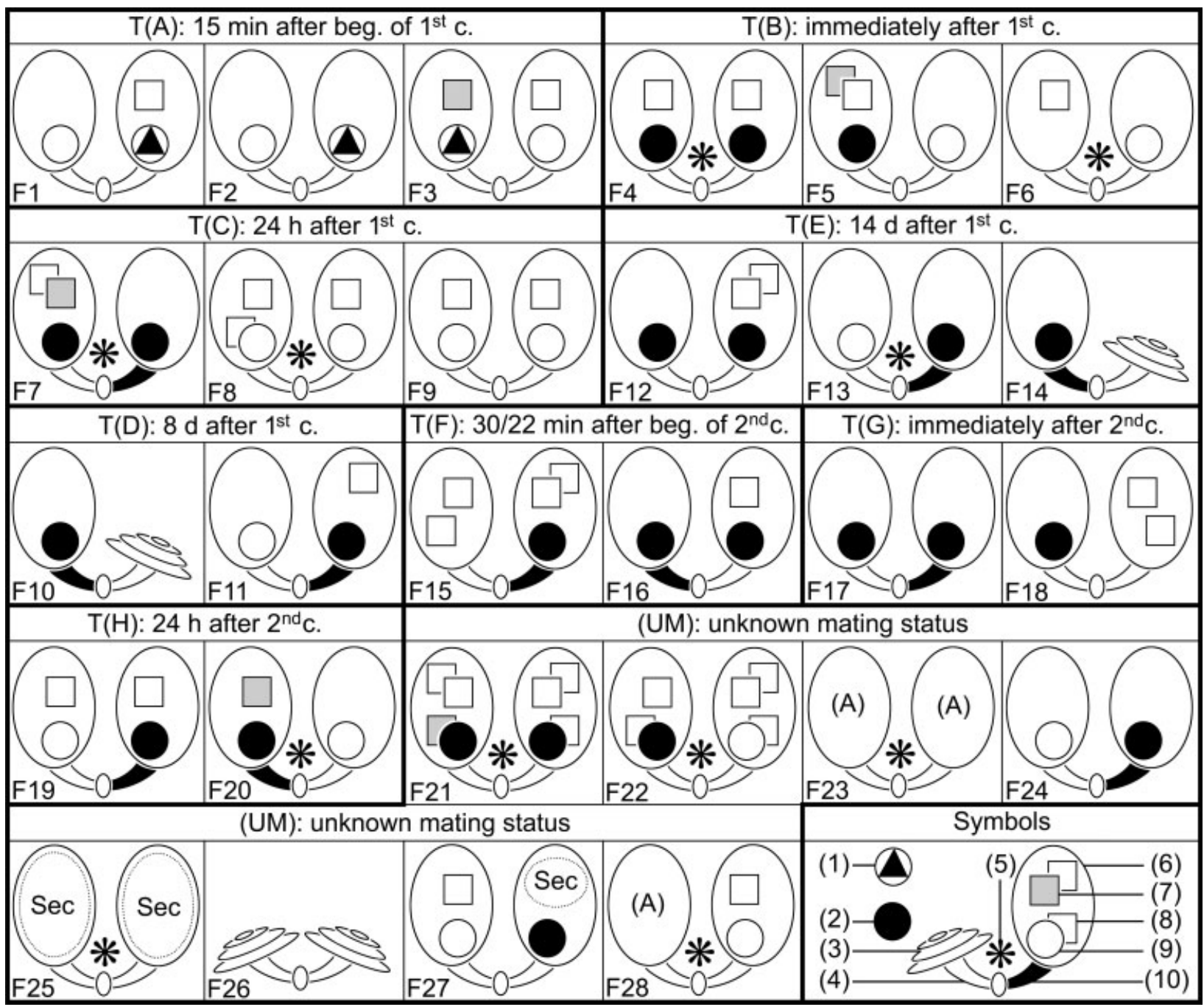

(A), content of receptaculum artificially destroyed during sectioning; beg., beginning; c., copulation; F1-F28, females 1-28; Sec, secretion; symbols: (1), spermatozoa embedded in secretion but not encapsulated in the thick secretion of a primary ball; (2), primary ball containing spermatozoa; (3), empty left receptaculum with folded cuticle; (4), empty left copulatory duct; (5), spermatozoa in the uterus internus; (6), right receptaculum; (7), secondary ball with undefined content (dark particles); (8), empty secondary ball; (9), empty primary ball; (10), spermatozoa in the right copulatory duct; T(A-H) (see Materials and Methods); UM, unknown mating status.

Resin, UK) and semithin serially sectioned (1 $\mu \mathrm{m})$ with a microtome (Leica RM 2145) using glass knives. The sections were stained with toluidine blue $(1 \%)$ in an aqueous borax solution (1\%) at $90^{\circ} \mathrm{C}$ for $18-20 \mathrm{~min}$. Five male palps (specimens collected on Doi Suthep) and the vulva of one female (collected on Doi Suthep) were embedded in Hoyers's medium and slide-mounted. Light microscopic studies were performed with a Zeiss Axioplan 2.

\section{Transmission Electron Microscopy}

Seven females (collected on Doi Suthep), which were not mated in the laboratory, were fixed in a solution of $2.5 \%$ glutaraldehyde in Na-cacodylate buffer $(0.1 \mathrm{M}, \mathrm{pH} 7.4)$ for $3 \mathrm{~h}$. The opisthosomae were then washed in Na-cacodylate buffer $(0.1$ $\mathrm{M}, \mathrm{pH}$ 7.4) for $15 \mathrm{~min}$, postfixed in $1 \%$ osmium tetroxide in Na-cacodylate buffer $(0.1 \mathrm{M}, \mathrm{pH} 7.4)$ for $2 \mathrm{~h}$, and washed again in Na-cacodylate buffer overnight. The specimens were dehy- drated in graded ethanols followed by propylene oxide and finally embedded in Epon. Ultrathin sections (70 nm) were cut with a diamond knife (Diatome SA, Bienne, Switzerland) on an ultramicrotome (Reichert Ultracut E), stained with uranyl acetate and lead citrate, and examined with a Philips CM 12 transmission electron microscope.

\section{Scanning Electron Microscopy}

The vulva of one female (collected on Doi Suthep) was isolated and kept in $5 \% \mathrm{KOH}$ solution for several days until the tissue was dissolved. The vulva and the prosoma of one male (collected on Doi Suthep) were dehydrated in graded ethanols, critical-point dried, gold sputtered, and examined with a Philips XL30 FEG scanning electron microscope. 

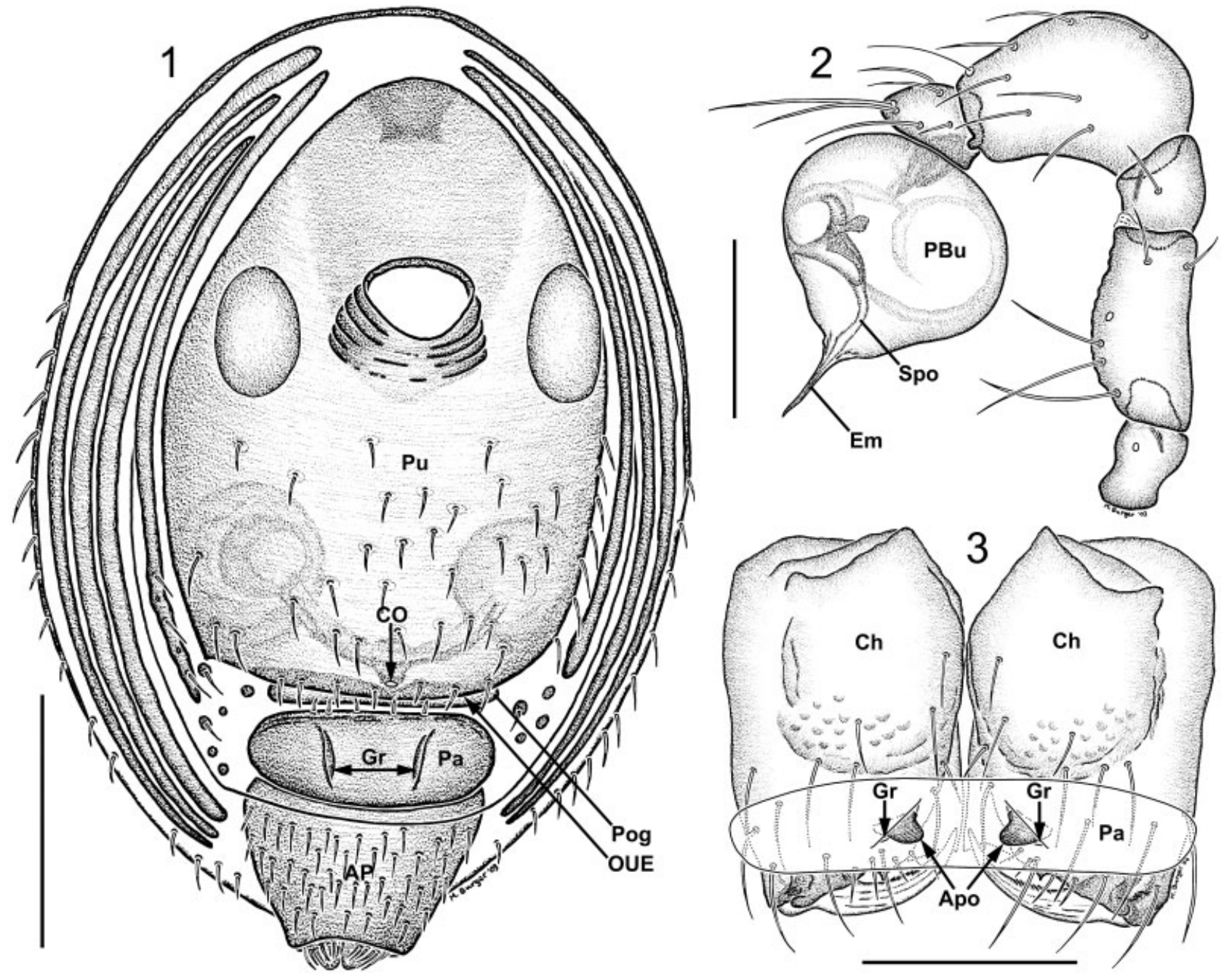

Figs. 1-3. Female and male of Indicoblemma lannaianum (modified from Burger, 2005). Fig. 1. Female opisthosoma, ventral view. Scale bar $=200 \mu \mathrm{m}$. Fig. 2. Left pedipalp of male, retrolateral view. Scale bar $=100 \mu \mathrm{m}$. Fig. 3. Male chelicerae and schematized preanal plate of female illustrating the locking mechanism during copulation. Scale bar $=100 \mu \mathrm{m}$. AP, anal plate; Apo, apophyses; Ch, chelicerae; CO, copulatory orifice; Em, embolus; Gr, grooves; OUE, opening of uterus externus; Pa, preanal plate; PBu, palpal bulb; Pog, postgenital plate; Pu, pulmonary plate; Spo, distal part of spermophore.

\section{RESULTS}

\section{Female Genital Organs}

Genital plates. The opisthosoma of Indicoblemma lannaianum is ventrally covered by four sclerotized plates (Fig. 1). The large pulmonary plate ( $\mathrm{Pu}$ in Figs. 1, 4, 7a,c, 8c) surrounding the pedicel is posteriorly followed by a short postgenital plate (Pog in Figs. 1, 4, 7a,c, 8c), a broad preanal plate ( $\mathrm{Pa}$ in Figs. 1, 3) with lengthwise lateral grooves ( $\mathrm{Gr}$ in Figs. 1, 3), and a conical anal plate (AP in Fig. 1) surrounding the spinnerets. There are two genital openings (Figs. 1, 4, 5, 7c,f, 8c): the small circular copulatory orifice (CO), which is situated near the posterior margin of the pulmonary plate, and the opening of the uterus externus (OUE) between the pulmonary plate and the postgenital plate.

Sclerotized vulval parts. The contours of the sclerotized vulval parts shine through the pulmo- nary plate of the opisthosoma (Fig. 1). The copulatory orifice leads into a narrow insertion duct (ID in Figs. 4, 5, 7c) which takes its course upwards. The insertion duct is curved slightly forward and ends in a strongly sclerotized median genital cavity (GC in Figs. 4, 5, 7c,g). The genital cavity continues laterally into paired copulatory ducts (CD in Figs. 4, $7 \mathrm{a}, \mathrm{d}, \mathrm{e}, \mathrm{h}, 8 \mathrm{~b}-\mathrm{d}, 9 \mathrm{a}, 10 \mathrm{c}, 12 \mathrm{a})$ that form closed tubes. The copulatory ducts are curved slightly forward and dorsally (Figs. 1, 4, 6, 7a, 8c, 10c. Note that the copulatory ducts in Figs. 6 and $7 \mathrm{a}$ are artificially strongly curved anteriorly due to preparation). Together they appear as a U-shaped tube with the strongly sclerotized median genital cavity (GC). The diameters of the copulatory ducts are smaller near the genital cavity $(\sim 15 \mu \mathrm{m}$; Figs. $4,7 \mathrm{a}, \mathrm{d})$ than laterally near the receptacula ( $\sim 25 \mu \mathrm{m}$; Figs. $4,7 \mathrm{a}, \mathrm{e})$. The posterior walls of the copulatory ducts are scle- 


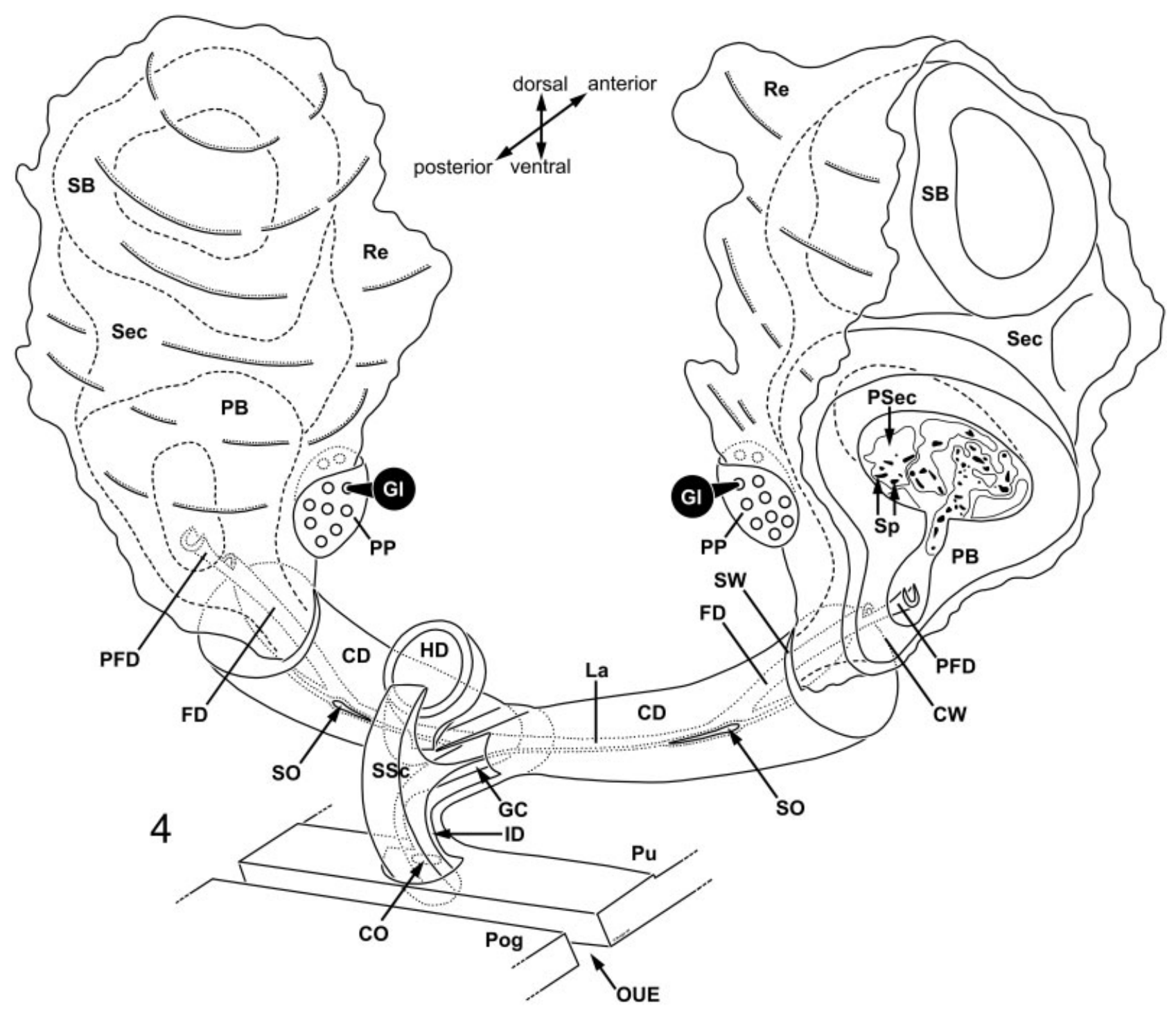

Fig. 4. Schematic drawing of the female genital region of Indicoblemma lannaianum. CD, copulatory duct; CO, copulatory orifice; CW, chitinized anterior wall of copulatory duct; FD, fertilization duct; GC, genital cavity; Gl, gland cells; HD, hemispherical depression; ID, insertion duct; La, lamella; OUE, opening of uterus externus; PB, primary ball; PFD, primary part of fertilization duct; Pog, postgenital plate; PP, pore plate; PSec, pinkish secretion; Pu, pulmonary plate; Re, receptaculum; SB, secondary ball; Sec, secretion; SO, slit-like opening of fertilization duct; Sp, spermatozoa; SSc, semi-circular sclerite; SW, sclerotized posterior wall of copulatory duct.

rotized (SW in Figs. 4, 10c, 12a), whereas their anterior walls appear chitinized only (CW in Figs. 4, $10 \mathrm{c}, 12 \mathrm{a})$.

Posterior to the insertion duct lies a semicircular sclerite (SSc in Figs. 4, 5, 7c) with a blunt distal part that is surrounded by the cuticle of the pulmonary plate (Figs. 4, 5, 7c). The proximal part of the sclerite is formed like a sharp edge (Figs. 4, 5, 7c). The dorsal wall of the genital cavity (GC) is not fused posteriorly with the sclerite (Figs. 5, 7c). A sclerotized lamella (La in Figs. 4, 5, 7a,c-e,g) extends anteriorly from the semicircular sclerite and reaches deeply into the genital cavity, thus separating it into a dorsal and a ventral part. The genital cavity is com- pletely separated by the lamella posteriorly (Figs. 4, $5,7 \mathrm{c}, \mathrm{g})$, whereas anteriorly the partition is incomplete, as the lamella does not reach the anterior wall of the genital cavity (Figs. 4, 5, 7c). The lamella continues laterally into both copulatory ducts (Figs. $4,5,7 \mathrm{~d}, \mathrm{e})$. It is fused with the sclerotized posterior walls of the copulatory ducts and reaches into their lumen (Figs. 4, 5, 7c-e). Near the genital cavity the posterior half of the copulatory ducts is separated by the lamella (Figs. 4, 5, 7d). Toward the lateral end of the copulatory ducts the lamella does not reach far into the lumen of the ducts any more (Figs. 4, 5, 7e). It becomes narrow and finally merges completely with the posterior wall of the copulatory ducts. 


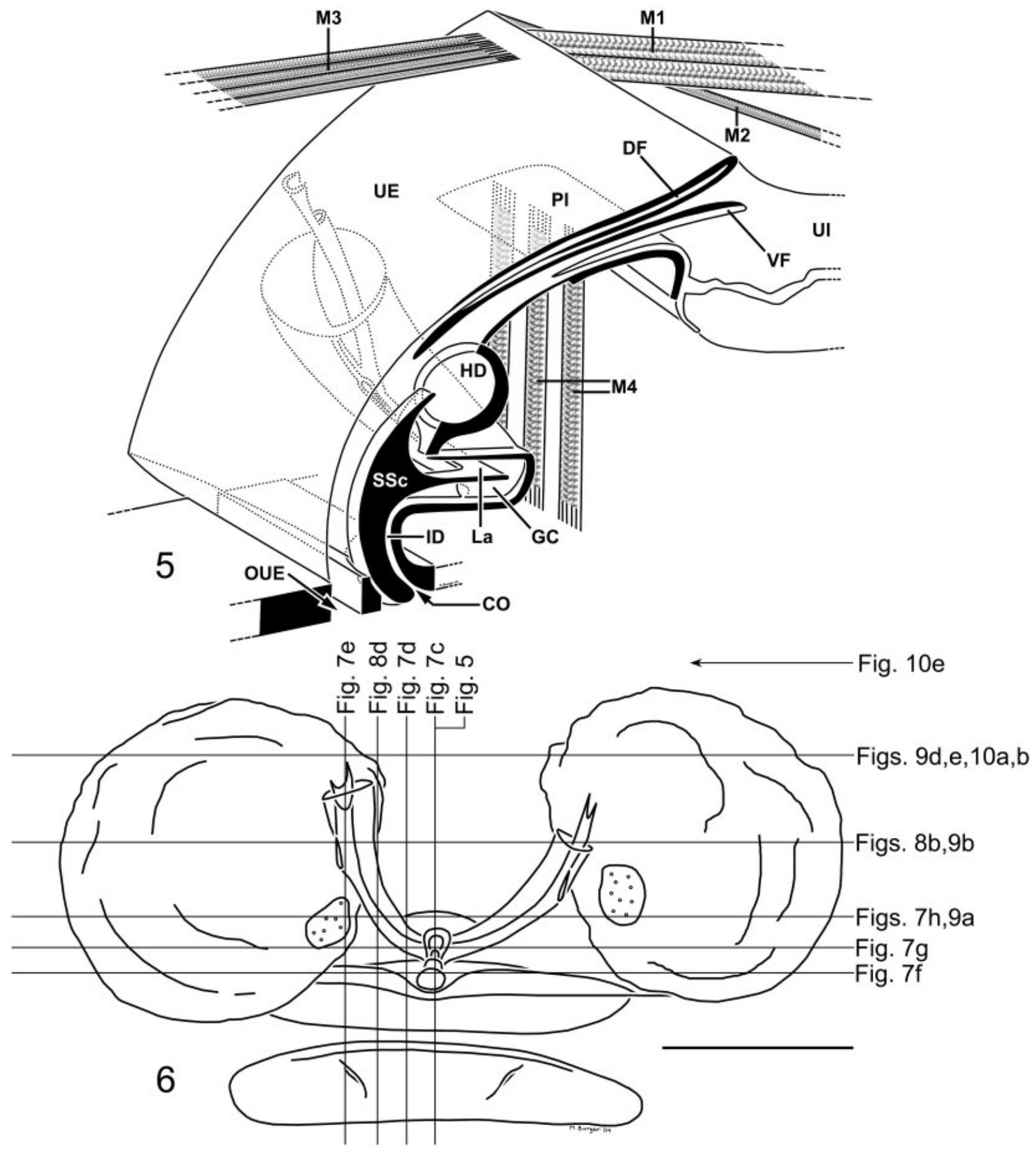

Figs. 5, 6. Schematic drawings of the female genital region of Indicoblemma lannaianum. Fig. 5. Longitudinally cut genital region. Fig. 6. Genital region, dorsal view, indicating the positions of the sections seen in Figures $7-10$. Scale bar $=100 \mu \mathrm{m}$. CO, copulatory orifice; DF, dorsal fold; GC, genital cavity; HD, hemispherical depression; ID, insertion duct; La, lamella; M1-M4, muscles 1-4; OUE, opening of uterus externus; Pl, sclerotized plate; SSc, semi-circular sclerite; UE, uterus externus; UI, uterus internus; VF, ventral fold.

Paired small fertilization ducts (FD in Figs. 4, $7 \mathrm{a}, \mathrm{h}, 8 \mathrm{c}, 9 \mathrm{a}, 12 \mathrm{a})$ originate inside the receptacula. They are curved and lead into the copulatory ducts
(Figs. 4, 7a,h, 8c, 9a, 12a). The fertilization ducts end in slit-like openings (SO in Figs. 4, 7a, 8c, 12a) situated in the sclerotized posterior wall of the cop- 


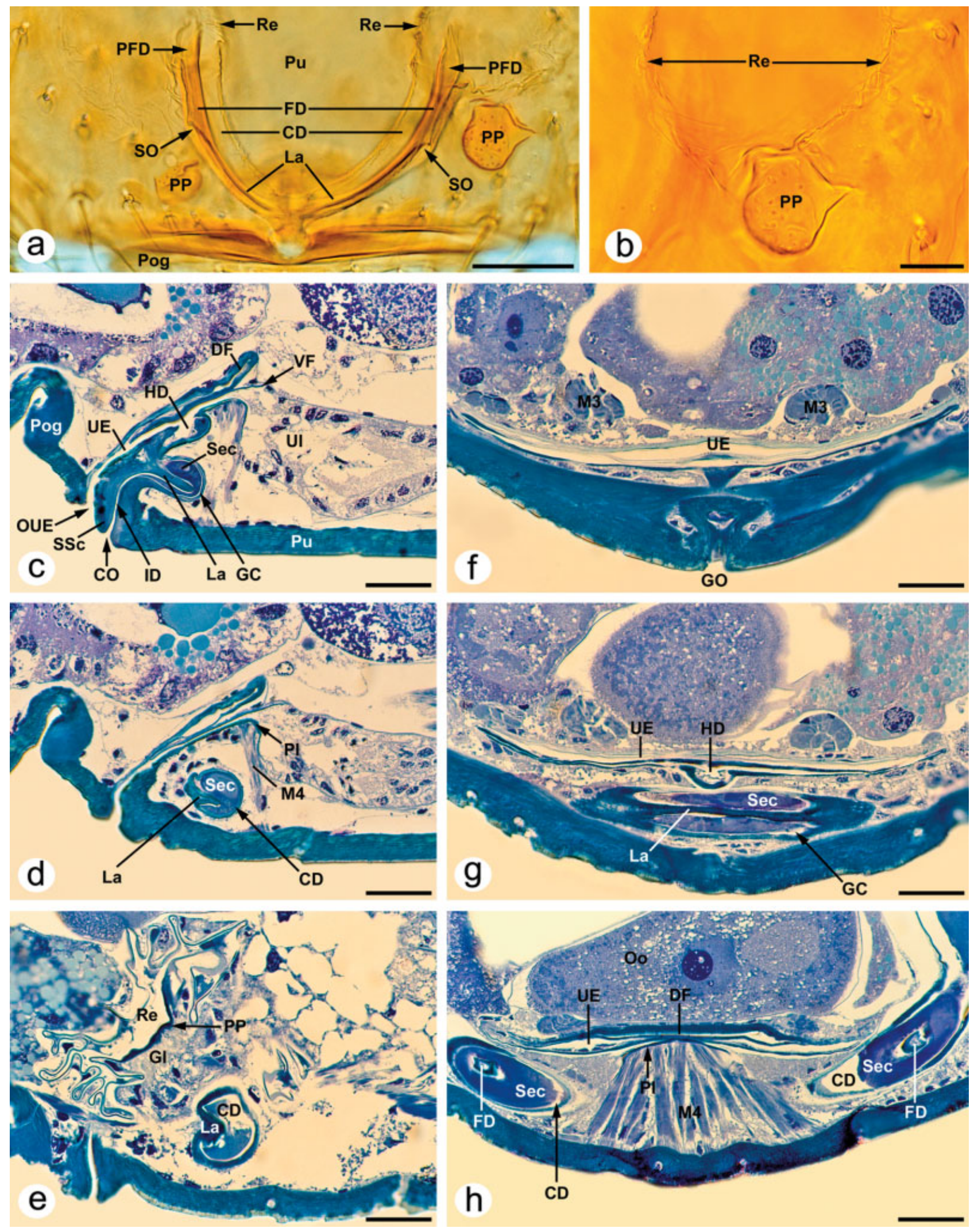

Fig. 7. Female genital region of Indicoblemma lannaianum. LM. a,b: Unstained vulva, dorsal view, slide-mounted. Scale bars $=$ $50 \mu \mathrm{m}(\mathbf{a}), 20 \mu \mathrm{m}(\mathbf{b})$. c-e: Serial longitudinal sections. Scale bars $=20 \mu \mathrm{m}$. f-h: Serial cross sections. Scale bars $=20 \mu \mathrm{m}$. CD copulatory duct; $\mathrm{CO}$, copulatory orifice; DF, dorsal fold; FD, fertilization duct; GC, genital cavity; Gl, gland cells; HD, hemispherical depression; ID, insertion duct; La, lamella; M3, M4, muscles 3, 4; Oo, oocyte; OUE, opening of uterus externus; PFD, primary part of fertilization duct; $\mathrm{Pl}$, sclerotized plate; Pog, postgenital plate; PP, pore plate; Pu, pulmonary plate; Re, receptaculum; Sec, secretion; SO, slit-like opening of fertilization duct; SSc, semi-circular sclerite; UE, uterus externus; UI, uterus internus; VF, ventral fold. 

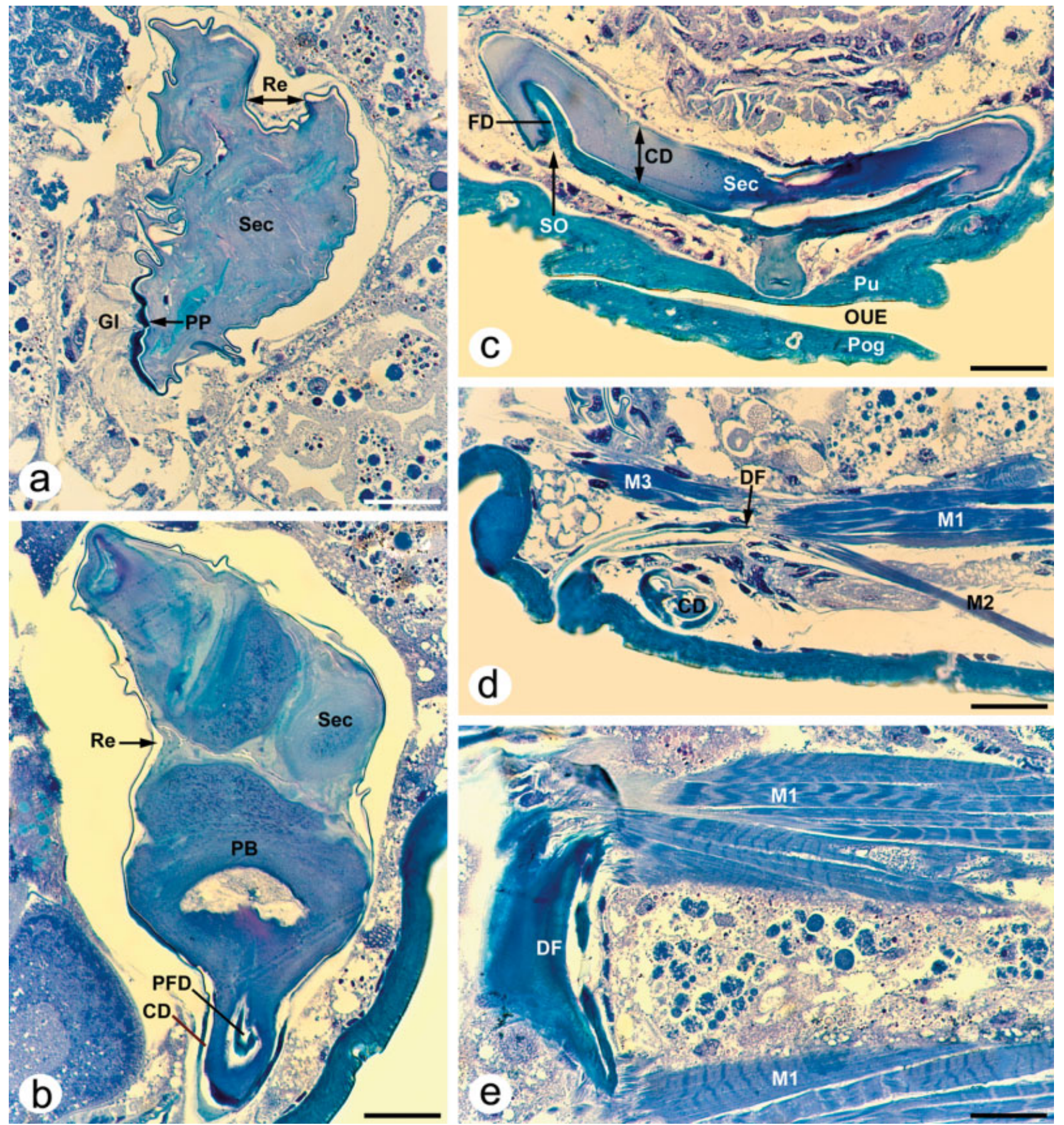

Fig. 8. Female genital region of Indicoblemma lannaianum. LM. a,c,e: Serial frontal sections. Scale bars $=20 \mu \mathrm{m}$. b: Cross section Scale bar $=20 \mu \mathrm{m}$. d: Longitudinal section. Scale bar $=20 \mu \mathrm{m}$. CD, copulatory duct; DF, dorsal fold; FD, fertilization duct; Gl, gland cells; M1-M3, muscles 1-3; OUE, opening of uterus externus; PB, primary ball; PFD, primary part of fertilization duct; Pog, postgenital plate; $\mathrm{PP}$, pore plate; $\mathrm{Pu}$, pulmonary plate; Re, receptaculum; Sec, secretion; SO, slit-like opening of fertilization duct.

ulatory ducts. The primary parts of the fertilization ducts (PFD in Figs. 4, 7a, 8b, 10a) are opened proximally and appear U-shaped. At the lateral end of the copulatory ducts the fertilization ducts begin to form completely closed tubes (Figs. 4, 7a,h, 9a).

Receptacula. Each copulatory duct leads into a large sac-like receptaculum (Re in Figs. 4, 7a,b,e,
$8 a, b, 9 b-e, 10 a, b, 11 a-c, 15,16)$. The cuticle of the receptacula is strongly folded (Figs. 4, 7a,b,e, 10b, $15,16)$ and directly attached to the posterior and anterior walls of the copulatory ducts (Figs. 4, 8b). An empty receptaculum appears like an interfolded sac with a small lumen (Fig. 7e). In nonempty receptacula (which are found in most females) huge 

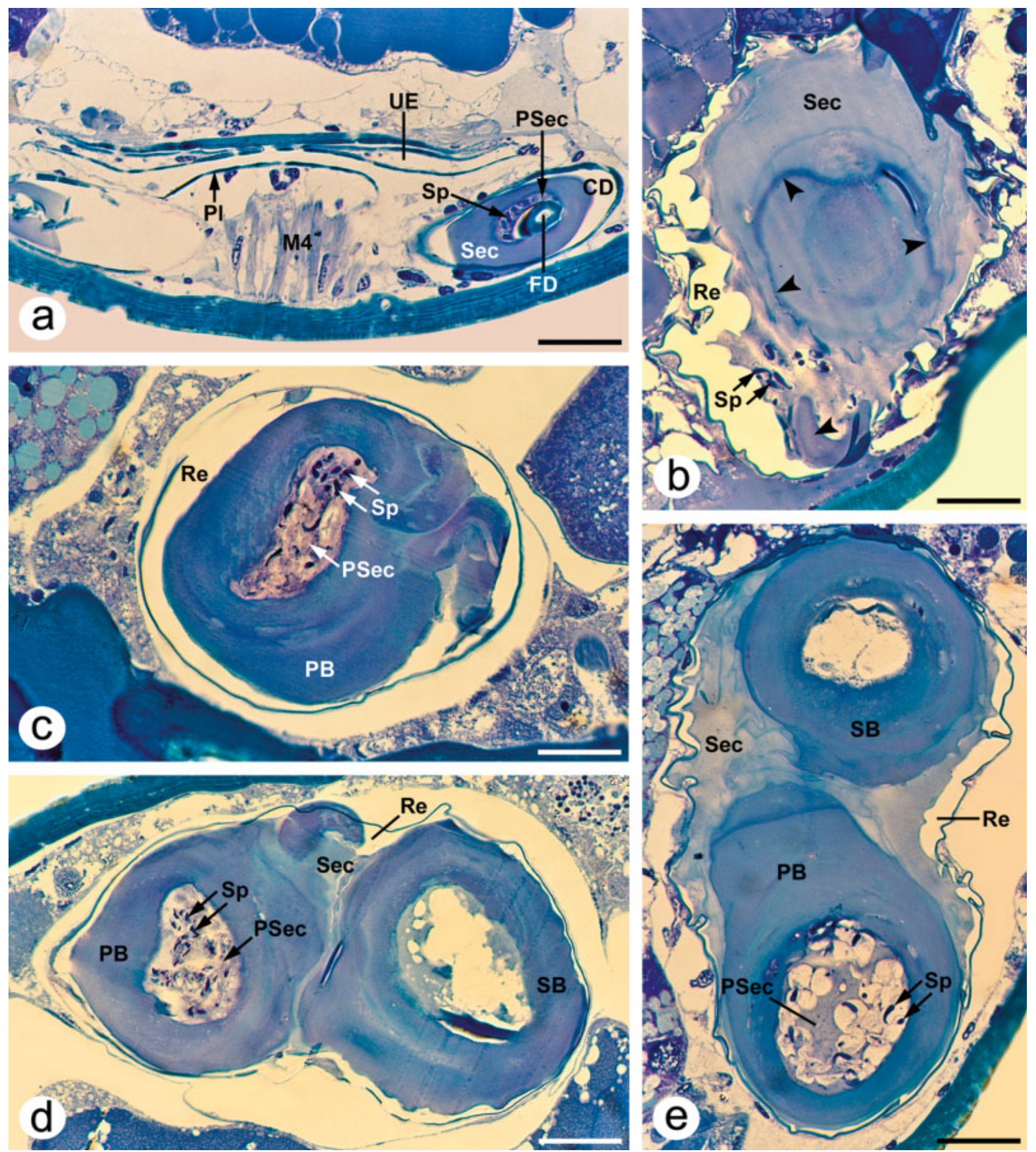

Fig. 9. Female genital region of Indicoblemma lannaianum. LM. a,b,d,e: Serial cross sections. Arrowheads in $\mathbf{b}$ indicate areas of dark blue secretion inside the receptaculum. Scale bars $=20 \mu \mathrm{m}$. c: Frontal section. Scale bar $=20 \mu \mathrm{m}$. CD, copulatory duct; FD, fertilization duct; M4, muscles 4; PB, primary ball; Pl, sclerotized plate; PSec, pinkish secretion; Re, receptaculum; SB, secondary ball; Sec, secretion; Sp, spermatozoa; UE, uterus externus.

masses of homogenous secretion are detectable (Sec in Figs. 4, 8a,b, 9b,d,e, 10a,b, 11a-c). Stained with toluidine blue the secretion appears light blue (Figs. $8 \mathrm{a}, \mathrm{b}, 9 \mathrm{~b}, \mathrm{~d}, \mathrm{e}, 10 \mathrm{a}, \mathrm{b})$. In some females it extends into the copulatory ducts and even fills the genital cavity
(Sec in Figs. 7c,d,g,h, 8c, 9a, 10c, 12a). The secretion is more dense (dark blue stained with toluidine blue) in some areas inside the receptacula. The dark blue secretion forms roundish secretory balls which are variable in size and position in different females 

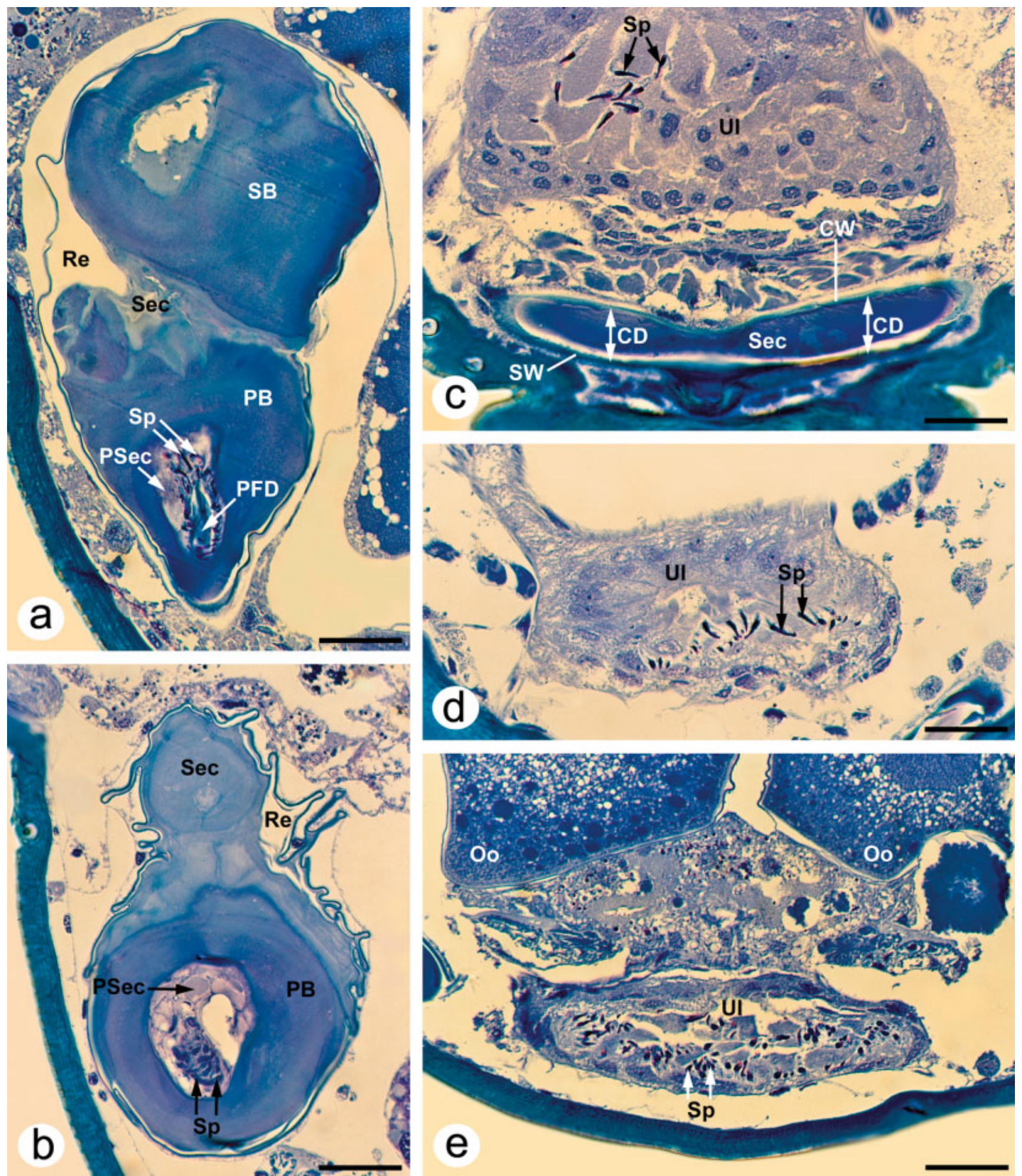

Fig. 10. Female genital region of Indicoblemma lannaianum. LM. a,b,e: Serial cross sections. Scale bars $=20 \mu \mathrm{m}$. c,d: Serial frontal sections. Scale bars $=20 \mu \mathrm{m}$. CD, copulatory duct; CW, chitinized anterior wall of copulatory duct; Oo, oocyte; PB, primary ball; PFD, primary part of fertilization duct; PSec, pinkish secretion; Re, receptaculum; SB, secondary ball; Sec, secretion; Sp, spermatozoa; SW, sclerotized posterior wall of copulatory duct; UI, uterus internus. 

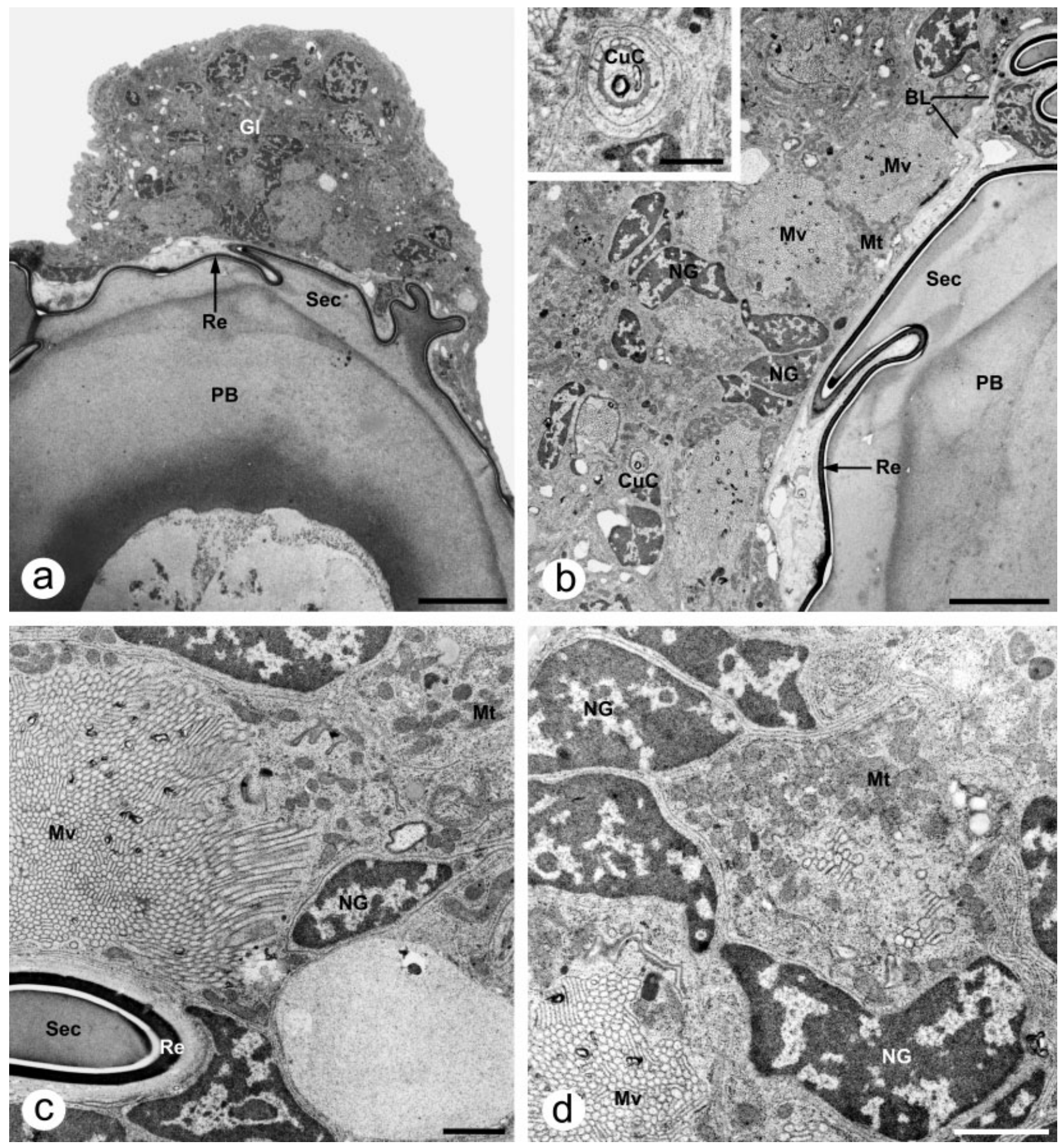

Fig. 11. Gland cells associated with the receptacula of female Indicoblemma lannaianum. TEM. Scale bars $=10 \mu \mathrm{m}(\mathbf{a}), 5 \mu \mathrm{m}(\mathbf{b})$, $1 \mu \mathrm{m}$ (b inset, c,d). BL, basal lamina of receptaculum; CuC, cuticular canal; Gl, gland cells; Mt, mitochondria; Mv, microvilli; NG, nucleus of gland cell; PB, primary ball; Re, receptaculum; Sec, secretion.

(Table 1, PB and SB in Figs. 4, 8b, 9c-e, 10a,b, $11 a, b)$. Two categories of secretory balls can be distinguished according to their position in the receptaculum: a primary ball (PB in Figs. 4, 8b, 9c-e, $10 a, b, 11 a, b)$ is situated closest to the lateral end of the copulatory duct at the distal part of the recep- taculum. The proximally opened primary part of the fertilization duct (PFD) always reaches into the lumen of a primary ball (Figs. 4, 8b, 10a). A secondary ball (SB in Figs. 4, 9d,e, 10a) is situated dorsally or anteriorly to a primary ball. Its lumen is never connected with the fertilization duct. 

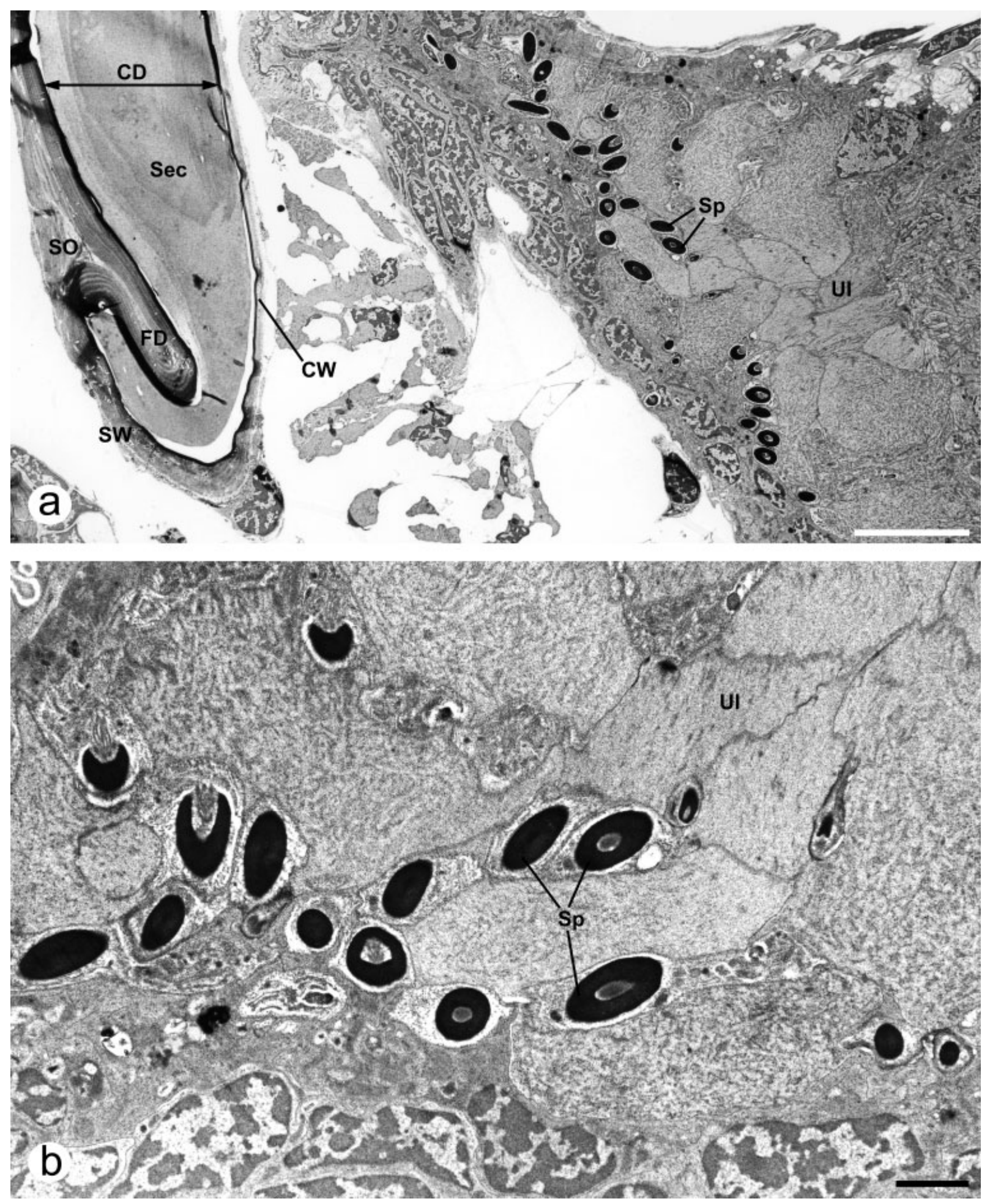

Fig. 12. Female genital region of Indicoblemma lannaianum. TEM. a: Copulatory duct and uterus internus with spermatozoa. Scale bar $=10 \mu \mathrm{m}$. b: Spermatozoa in the uterus internus. Scale bar $=2 \mu \mathrm{m}$. CD, copulatory duct; CW, chitinized anterior wall of copulatory duct; FD, fertilization duct; Sec, secretion; SO, slit-like opening of fertilization duct; Sp, spermatozoa; SW, sclerotized posterior wall of copulatory duct; UI, uterus internus.

The number of primary and secondary balls is variable in different females (Table 1). It ranges from no ball at all (F25 and F26) to eight balls (F21, four balls in each receptaculum). In females without secretory balls the receptacula appear either filled with homogenous light blue secretion (F25, Sec in 

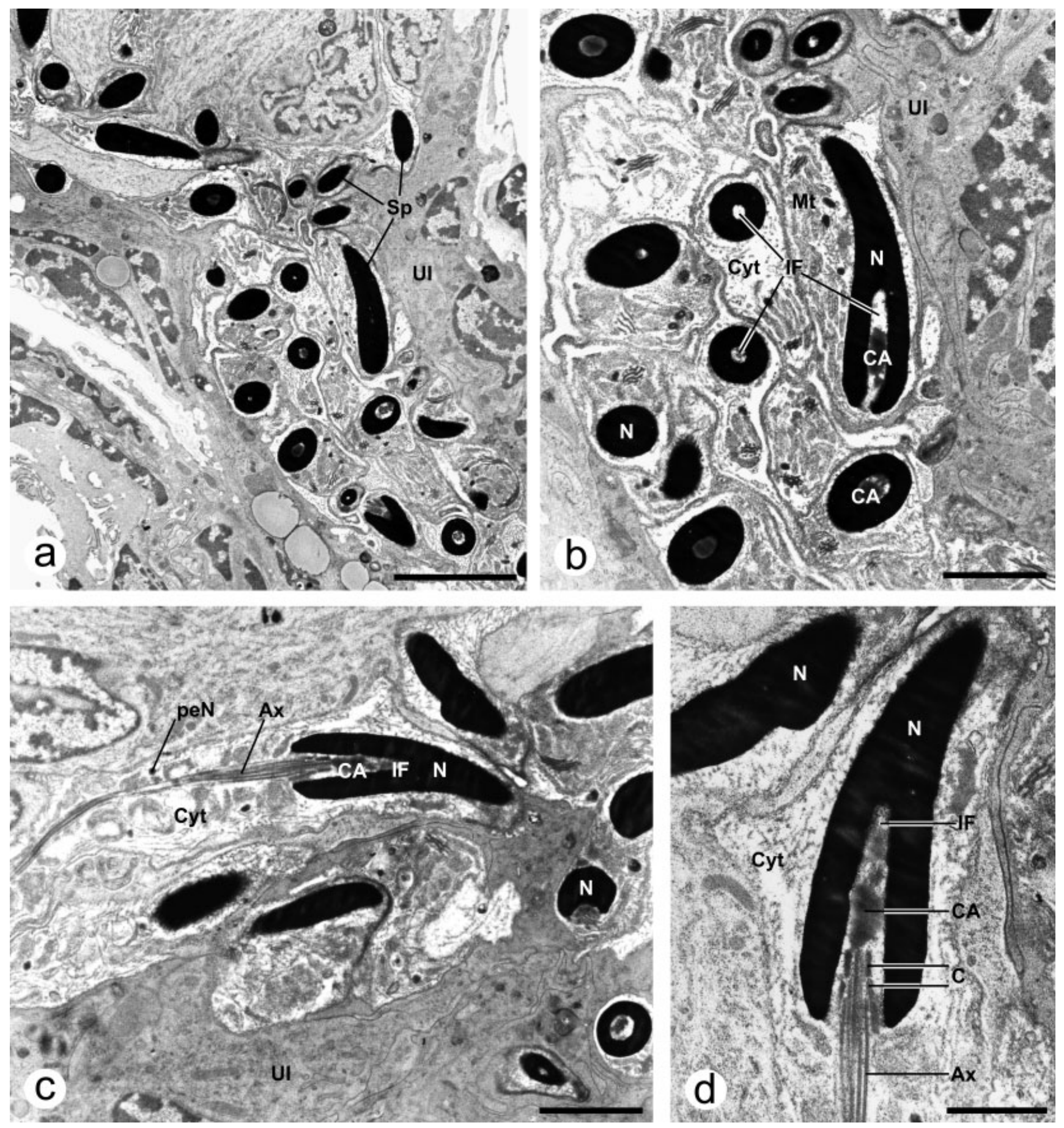

Fig. 13. Spermatozoa in the uterus internus of female Indicoblemma lannaianum. TEM. Scale bars $=5 \mu \mathrm{m}(\mathbf{a}), 2 \mu \mathrm{m}(\mathbf{b}, \mathbf{c}), 1 \mu \mathrm{m}$ (d). Ax, axoneme; CA, centriolar adjunct; C, centrioles; Cyt, cytoplasm; IF, implantation fossa; Mt, mitochondria; N, nucleus of spermatozoa; peN, postcentriolar elongation of nucleus; Sp, spermatozoa; UI, uterus internus.

Fig. 8a) or completely folded without secretion in it (F26, Re in Fig. 7e).

Glandular region. Both receptacula have a sclerotized pore plate (PP in Figs. 4, 7a,b,e, 8a) mesally with associated gland cells (Gl in Figs. 4, 7e, 8a, 11a). The gland cells extend around the pore plate (Fig. 11a). Figure 11 shows the different components of the gland cells of a receptaculum (Re in Fig. $11 \mathrm{a}-\mathrm{c})$ containing one primary ball ( $\mathrm{PB}$ in Fig. $11 \mathrm{a}, \mathrm{b})$. The flat epithelium of the receptaculum possesses a thick basal lamina (BL in Fig. 11b) and borders the adjacent gland cells of the pore plate (Fig. 11a,b). Inside the glandular epithelium are cuticular canals built by several cells $(\mathrm{CuC}$ in Fig. 

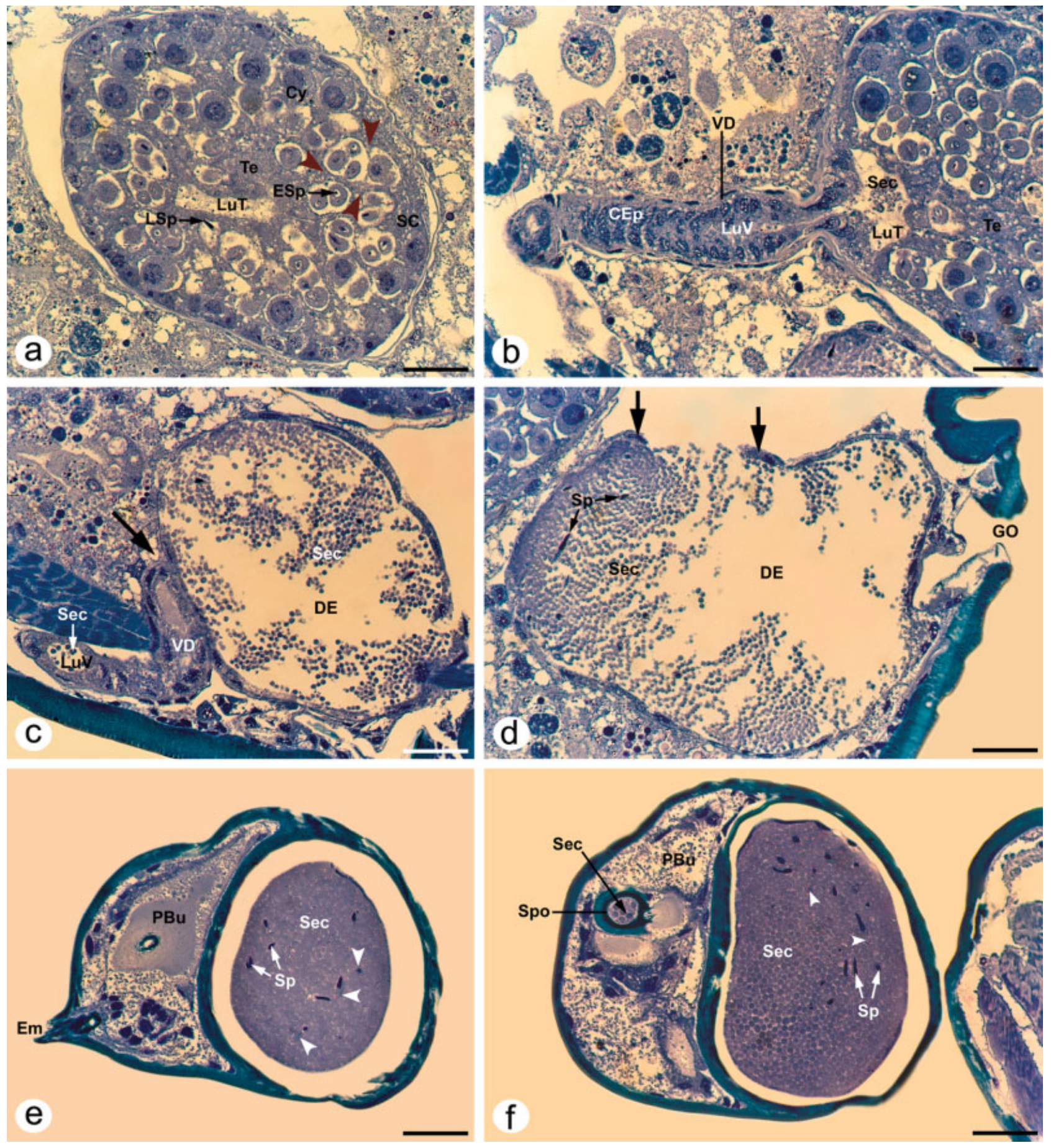

Fig. 14. Male genital organs of Indicoblemma lannaianum. LM. a,b: Serial longitudinal sections through testes and vas deferens. Arrowheads indicate extensions of the somatic cells. Scale bars $=20 \mu \mathrm{m}$. c,d: Serial longitudinal sections through vas deferens and ductus ejaculatorius. Large arrow in $\mathbf{c}$ indicates opening of vas deferens into ductus ejaculatorius. Large arrows in $\mathbf{d}$ indicate flat epithelium of ductus ejaculatorius. Scale bars $=20 \mu \mathrm{m}$. e,f: Serial longitudinal sections through the palpal bulb. Arrowheads indicate sheaths around the spermatozoa. Scale bars $=20 \mu \mathrm{m}$. CEp, cuboidal epithelium of vas deferens; Cy, cysts; DE, ductus ejaculatorius; Em, embolus; ESp, early stage spermatid; GO, genital opening; LSp, late stage spermatid; LuT, lumen of testes; LuV, lumen of vas deferens; PBu, palpal bulb; SC, somatic cells; Sec, secretion; Sp, spermatozoa; Spo, distal part of spermophore; Te, testes; VD, vas deferens.

$11 \mathrm{~b}$ and inset). Figure $11 \mathrm{~b}-\mathrm{d}$ shows the densely arranged microvilli $(\mathrm{Mv})$, the nuclei of the gland cells (NG), and regions rich in mitochondria (Mt) within the gland cells.
Uterus externus. The uterus externus (UE in Figs. 5, 7c,f-h, 9a, 15) takes its course between the receptacula (Figs. 5, 7d,h, 9a, 15). The semicircular sclerite (SSc) lies in the anterior wall of 

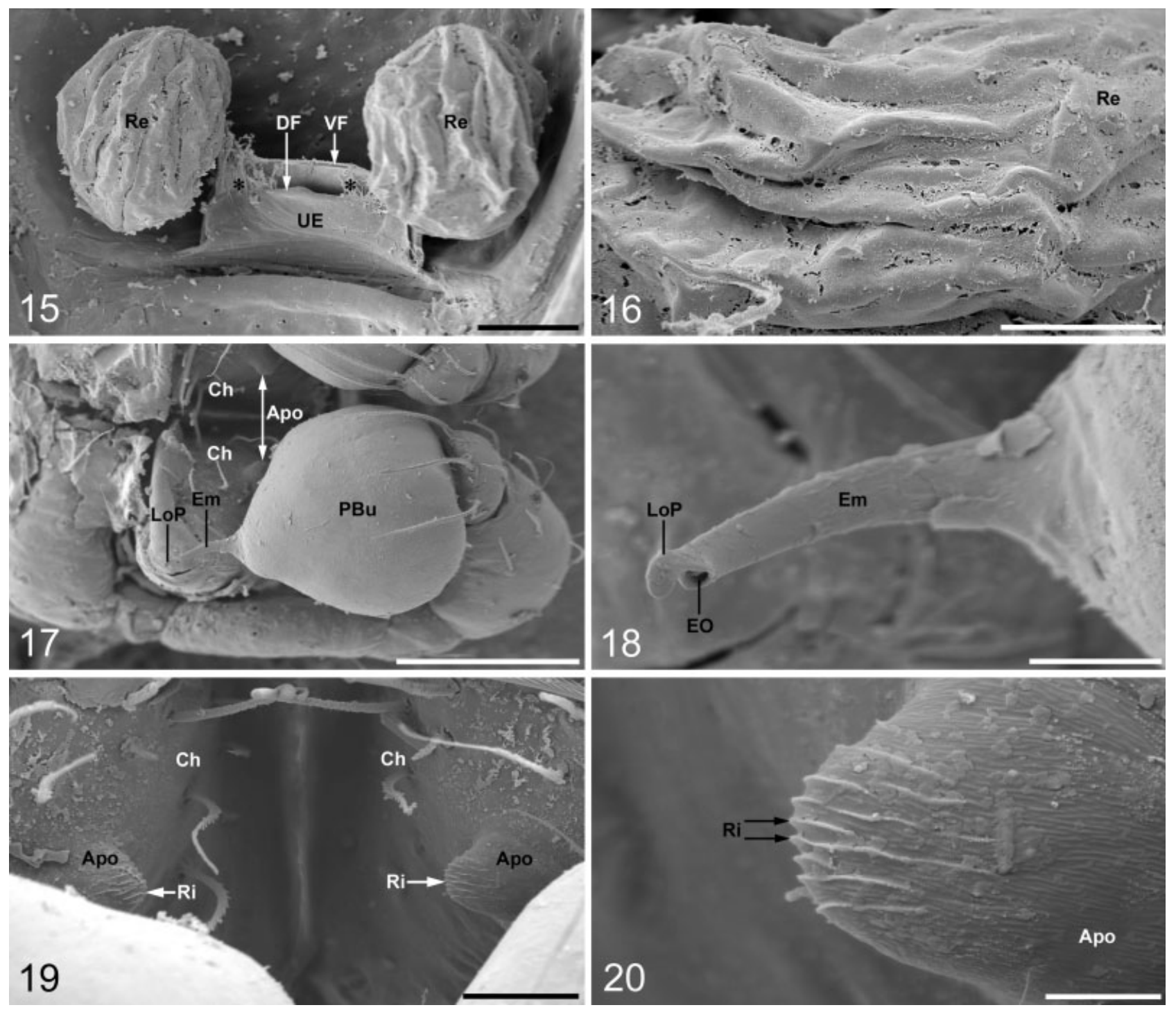

Figs. 15-20. Female and male genital organs of Indicoblemma lannaianum. SEM. Fig. 15. Vulva, dorsal view. Asterisks indicate attachments of muscles M3 on the dorsal fold of the uterus externus. Scale bar $=50 \mu \mathrm{m}$. Fig. 16 . Folds of receptaculum. Scale bar $=$ $20 \mu \mathrm{m}$. Fig. 17. Male palp. Scale bar $=100 \mu \mathrm{m}$. Fig. 18. Embolus of male palp. Scale bar $=10 \mu \mathrm{m}$. Figs. 19, 20. Apophyses on male chelicerae. Scale bars $=20 \mu \mathrm{m}$ (19), $5 \mu \mathrm{m}$ (20). Apo, apophyses; Ch, chelicerae; DF, dorsal fold; Em, embolus; EO, embolus opening; LoP, lob-like protrusion on embolus; PBu, palpal bulb; Re, receptaculum; Ri, ridges; UE, uterus externus; VF, ventral fold.

the uterus externus (Figs. 5, 7c) as well as a sclerotized hemispherical depression (HD in Figs. 4, 5, $7 \mathrm{c}, \mathrm{g})$ following the semicircular sclerite dorsally. The uterus externus shows a strongly sclerotized dorsal fold (DF in Figs. 5, 7c,h, 8d,e, 15) and a lesser sclerotized fold (VF in Figs. 5, 7c, 15) that is situated more ventrally. A sclerotized plate ( $\mathrm{Pl}$ in Figs. 5, 7d,h, 9a) lies ventral of the folds in the anterior wall of the uterus externus. Anterior to the folds and the sclerotized plate the uterus externus fuses with the uterus internus (UI in Figs. $5,7 \mathrm{c}, 10 \mathrm{c}-\mathrm{e}, 12,13 \mathrm{a}-\mathrm{c})$. The large oocytes $(\mathrm{Oo})$ are illustrated in Figures $7 \mathrm{~h}$ and $10 \mathrm{e}$.

\section{Muscles Associated With the Female Genital Organs}

The sclerotized dorsal fold (DF) of the uterus externus serves as muscle attachment for a paired set of massive muscles (M1 in Figs. 5, 8d,e, asterisks in Fig. 15) that are directed anteriorly and end near the pedicel, and an additional pair of thin muscles (M2 in Figs. 5, 8d) that run anteriorly and ventrally ending on the pulmonary plate. A paired set of muscles (M3 in Figs. 5, 7f, 8d) originating at the sclerotized dorsal fold (DF) is directed posteriorly and ends near the spinnerets. The sclerotized plate $(\mathrm{Pl})$ situated in the anterior wall of the uterus externus 
serves as attachment for the muscles M4 (Figs. 5, $7 \mathrm{~d}, \mathrm{~h}, 9 \mathrm{a})$ that run ventrally and end on the pulmonary plate.

\section{Sperm Characterization and Location Inside the Female Genital Organs}

In a copulatory duct. Eleven females of different mating status had spermatozoa in one copulatory duct (Table 1; Sp in Fig. 9a). The spermatozoa were densely packed and embedded in a pinkish secretion (stained with toluidine blue; Psec in Fig. 9a). This particular duct always leads to a receptaculum having a sperm-containing primary ball (Table 1). In no female was sperm found in both copulatory ducts. A comparison of F4-F9, i.e., the six females of T(B) (immediately after the first copulation, Table 1) and $\mathrm{T}(\mathrm{C})$ (24 h after the first copulation, Table 1), with F17-F20, i.e., the four females of T(G) (immediately after the second copulation, Table 1) and $\mathrm{T}(\mathrm{H})$ (24 $\mathrm{h}$ after the second copulation, Table 1 ), reveals that one out of six single-mated females have spermatozoa in a copulatory duct as opposed to three out of four double-mated females.

Embedded in secretion. In all three females of T(A) (15 min after the beginning of the first copulation) spermatozoa are present at the lateral end of one copulatory duct where it continues into the receptaculum (Table 1; Sp in Fig. 9b). The spermatozoa are embedded in a light blue secretion of lower density (Sec in Fig. 9b) but are not encapsulated in a secretory ball. Several areas of dark blue secretion of higher density are detectable around the spermatozoa inside the receptaculum (arrowheads in Fig. $9 b)$.

Encapsulated in one or two primary balls. Twelve females of different mating status have spermatozoa encapsulated in only one primary ball (Table 1; Sp in Figs. 4, 9c-e, 10a,b). The spermatozoa are embedded in a pinkish secretion (Psec in Figs. 4, $9 c-e, 10 a, b)$ encapsulated by the thick secretion of the ball (PB in Figs. 4, 9c-e, 10a,b). In the primary balls of Figure 9c,d the spermatozoa still seem to be in their compact transfer form, whereas in Figure 9e they start to decapsulate, as indicated by the dilated bright areas around the dark nuclei. An empty primary ball is present in the opposite receptaculum of all these females except for four females whose opposite receptacula are either empty or contain empty secondary balls (Table 1).

Six females of different mating status had spermatozoa encapsulated in two primary balls-one in each receptaculum (Table 1). The spermatozoa appear in the same form as described in the paragraph above. Considering empty and sperm-containing primary balls, the six single-mated females of $\mathrm{T}(\mathrm{B})$ and $\mathrm{T}(\mathrm{C})$ together (Table 1 ) have on the average 1.8 primary balls per female in their receptacula (five females with two and one female with one primary ball). The situation in the four double-mated females of $\mathrm{T}(\mathrm{G})$ and $\mathrm{T}(\mathrm{H})$ together (Table 1) seems to be similar (three females with two and one female with one primary ball).

In the uterus internus. Masses of spermatozoa were present in the uterus internus of 11 females of different mating status (Table 1) and in two females prepared for the TEM studies (Sp in Figs. 10c-e, 12, 13a). In five of these females no additional sperm is found in the copulatory duct or the receptacula (note that the contents of both receptacula of F23 and the left receptaculum of F28 were artificially destroyed during sectioning; (A) in Table 1). The spermatozoa are situated between the apices of the cells of the uterus internus and are often grouped together (Figs. 12, 13). The sperm cells are uncoiled and characterized by an extensive cytoplasm (Cyt in Fig. $13 \mathrm{~b}-\mathrm{d}$ ). The elongated nucleus ( $\mathrm{N}$ in Fig. 13b-d) is cone-shaped and possesses a tube-like implantation fossa (IF in Fig. 13b-d) filled with the dense centriolar adjunct (CA in Fig. 13b-d). Within the cytoplasm, mitochondria (Mt in Fig. 13b) and further cell components are visible. The postcentriolar elongation of the nucleus (peN in Fig. 13c) is a very thin tube that turns around the axoneme (Ax in Fig. $13 \mathrm{c}, \mathrm{d})$. The axoneme possesses inner and outer tubuli and the centrioles (C in Fig. 13d) are oriented in tandem position.

Absence of sperm. Spermatozoa are never found encapsulated in secondary balls. The secondary balls are always empty (Table 1, Figs. 4, 9d,e, 10a), except for five cases where they seem to contain dark particles (Table 1). The number of secondary balls found in a female ranges from zero to six (Table 1). F9 and F26 have no sperm at all inside their genital structures (Table 1). Sperm is never found in the uterus externus.

\section{Male Genital Organs and Cheliceral Modifications}

Male genital system. The genital system of the Indicoblemma lannaianum male we studied consists of thick testes (Te in Fig. 14a,b) and thin convoluted vasa deferentia (VD in Fig. 14b,c). Within the small testes the different developmental stages of spermatogenesis are visible (Fig. 14a,b). The spermatids are arranged in cysts (Cy in Fig. 14a) that are surrounded by extensions of the somatic cells (SC and arrowheads in Fig. 14a). Dark and elongated, thin nuclei characterize late-stage spermatids (LSp in Fig. 14a), whereas large roundish nuclei are typical for spermatogonia and early stages of spermatogenesis (ESp in Fig. 14a). The nuclei of the somatic cells are irregularly shaped and located in the periphery of the testes (Fig. 14a). The lumen in the center of the testes (LuT in Fig. 14a,b) is partly filled with secretion (Sec in Fig. 14b). The connection between the testis and the tube-like vas deferens is very narrow (Fig. 14b). The vas deferens possesses a thick cuboidal epithelium (CEp in Fig. 14b) and a 
narrow lumen (LuV in Fig. 14b,c) filled with secretion and some sperm cells (Fig. 14b,c). The vasa deferentia open into the wide ductus ejaculatorius (DE in Fig. 14c, large arrow). The ductus ejaculatorius is filled with very few spermatozoa ( $\mathrm{Sp}$ in Fig. 14d) that are embedded in a large amount of globular secretion (Sec in Fig. 14c,d), likely produced in the testes and vasa deferentia. The epithelium of the ductus ejaculatorius is flat (Fig. 14d, large arrows). Finally, the ductus ejaculatorius leads into the genital opening (GO in Fig. 14d).

Palpal bulb. The voluminous globular palpal bulb (PBu in Figs. 2, 14e,f, 17) of the Indicoblemma lannaianum male we studied is filled with seminal fluid consisting predominately of globular secretion (Sec in Fig. 14e,f) in which a few spermatozoa are embedded (Sp in Fig. 14e,f). The spermatozoa are encapsulated by a sheath produced in the genital system (arrowheads in Fig. 14e,f). The palpal bulb continues into a short embolus (Em in Figs. 2, 14e, 17,18 ) with a simple tip. The opening of the embolus (EO in Fig. 18) is accompanied by a small lobe-like protrusion (LoP in Figs. 17, 18). The distal part of the spermophore (Spo in Figs. 2, 14f) shines through the cuticle of the palpal bulb (Fig. 2).

Chelicerae. The male chelicerae (Ch in Figs. 3, $17,19)$ are modified in the context of copulatory mechanics. They bear two small blunt dark apophyses (Apo in Figs. 3, 17, 19, 20) on the anterior distal surface covered with fine lengthwise ridges ( $\mathrm{Ri}$ in Figs. 19, 20).

\section{DISCUSSION}

\section{Female Genital Organs and Sperm Encapsulation}

Several studies revealed that the genital organs of some haplogynes do not correspond to the description of a haplogyne vulva by Whiele (1967) and Austad (1984) (Cooke, 1966; Uhl, 1994a,b, 2000; Huber, 2002; Burger et al., 2003). The present investigation on Indicoblemma lannaianum is another example of complex haplogyne genital structures. Females have masses of secretion in the receptacula. Secretions produced by accessory glands to the receptacula are found in haplogynes (Kovoor, 1981; Coyle et al., 1983; Uhl, 1994a,b, 1996; Michalik et al., 2005a) and in entelegynes (Suhm and Alberti, 1993, 1996; Berendonck and Greven, 2005). A gel-electrophoretic analysis of the secretion of Pholcus phalangioides revealed proteinaceous substances with glyco- and lipoprotein components (Uhl, 1996). The function of such secretions inside the female genital organs could not be definitely clarified as yet. Providing nutrition to the spermatozoa could be a reason (Uhl, 1996; Berendonck and Greven, 2005; Michalik et al., 2005a), as well as sperm activation by certain components of the secretion (Uhl, 1996, 2002; Michalik et al., 2005a).
However, an important function of the secretion in Indicoblemma lannaianum seems to be the encapsulation of sperm in discrete packages (secretory balls). In this way, the mixing of sperm from different males inside the receptacula may be avoided. Therefore, sperm competition may be completely prevented or at least severely limited. Females seem to have full control over transferred sperm and be able to express a preference for spermatozoa of certain males. Only a few spermatozoa were found in the palpal bulb of the male we investigated. If the low amount of spermatozoa in the male palpal bulb is the general state, then it further suggests that no sperm competition occurs within the female (e.g., Wedell et al., 2002).

The process of sperm encapsulation in a secretory ball seems to begin early during copulation. In F1F3, i.e., all females of T(A), sperm is not yet encapsulated in a secretory ball. Areas of secretion of higher density seem to arise at the same time, indicating the beginning of sperm encapsulation in a primary ball. The female secretion should be produced by the glands associated with the pore plates on the receptacula, as there are no other glands in the genital region. As cuticular canals are detectable, these glands may consist of glandular units and therefore belong to class III (Noirot and Quennedey, 1991; Quennedey, 1998). We assume that the secretions in females at least partly consist of the secretion found in the seminal fluid of males.

Brignoli (1974) observed strands of coagulated liquid on the tips of the pedipalps of some tetrablemmid males and suggested that they transfer spermatophores. This assumption was doubted by Lehtinen (1981) and by us. Spermatophores in spiders are unusual and only proposed for one telemid species so far (Juberthie et al., 1981), where the "spermatophores" are more likely aggregated cleistospermia (Alberti, 2000; Michalik et al., 2004a). However, no spermatophores were found in the male genital organs of Indicoblemma lannaianum.

\section{Internal Fertilization}

In general, fertilization in spiders is considered to take place in the distal part of the uterus (Foelix, 1996; Morishita et al., 2003). However, this has not been demonstrated yet and was only suggested according to the morphology of the female genital tract (Alberti and Michalik, 2004). The time of sperm incorporation into the egg (which would actually be the fertilization) remains unknown (Suzuki, 1995; Alberti and Michalik, 2004). A study on an entelegyne spider indicates that fertilization could happen in the ovary (Suzuki, 1995; see also Alberti and Michalik, 2004). However, the possibility that the location of fertilization could be different within entelegyne or haplogyne species has not been seriously taken into account yet (Alberti and Michalik, 2004; Michalik et al., 2005a). In Indicoblemma lannaia- 
num, distinct ducts lead from the lumen of the sperm-containing secretory balls to slit-like openings in the posterior wall of the copulatory ducts. The ducts are called "fertilization ducts" in the present study because passing these ducts seems to be the only possibility for the spermatozoa to leave the secretory balls in order to fertilize the eggs. It is strongly assumed that the spermatozoa in the uterus internus of I. lannaianum are used for fertilization. They are activated, as they lack the secretion envelope and the flagellum is clearly visible. The spermatozoa could even migrate to the ovary and fertilize the eggs, as has been reported for mites and ticks (Alberti and Coons, 1999; Coons and Alberti, 1999). In any case, the present study provides evidence for internal fertilization (meaning in the uterus internus or the ovary) of a haplogyne spider.

There is a connection between the genital cavity (GC) and the uterus externus. The lamella (La) may efficiently prevent the comparatively short embolus from reaching the hemispherical depression (HD), and thus no sperm can be deposited to the uterus externus. One female (F25 in Table 1) had spermatozoa in the uterus internus but no secretory balls in the receptacula. This could be an indication that in exceptional cases males could be able to deposit sperm directly into the uterus by inserting the embolus in the opening of the uterus externus. Females are not able to lock the uterus externus during copulation, at least not by muscle contractions, as occurs in the oonopid Opopaea fosuma (Burger et al., 2003). However, females of Indicoblemma lannaianum might be able to deter males from inserting the embolus into the opening of the uterus externus. Also, the fact that sperm was never found in the uterus externus is an argument against direct sperm transfer into the uterus by the male because the uterus externus needs to be passed for sperm deposition into the uterus internus. In addition, the male embolus is too short to reach the uterus internus.

During oviposition, the large oocytes have to pass the comparatively narrow uterus externus. A simultaneous contraction of muscles M1-M4 may lead to a widening of the dorsal and the ventral fold (DF and VF), and thus to a considerable expansion of the uterus externus lumen. The folds are unfolded, which may create enough space for the oocytes. The pressure especially caused by the contraction of muscles M4 may lead to a compression of the copulatory ducts, which is possible because of their flexible chitinized anterior walls. This compression during oviposition may also lead to a slight movement of the copulatory ducts ventrally. This movement is possible because the dorsal wall of the sclerotized genital cavity (GC) is not fused with the rigid sclerite (SSc) and because the lamella (La) extending from the sclerite is not fused with the anterior wall of the genital cavity.

\section{Sperm Priority Pattern}

If our interpretations of the female genital system of Indicoblemma lannaianum are correct, it seems that the encapsulation of spermatozoa in secretory balls, which are connected with the fertilization ducts, may give the female control in determining a sperm priority pattern. Assuming first male priority, the spermatozoa of the first male that achieves copulation would be encapsulated in a primary ball. It seems that there is no difference in the number of primary balls per female in single- and doublemated females. The spermatozoa in the primary ball should be used for fertilization. After fertilization the now empty primary ball may get in the position of a secondary ball. Sperm is never found in secondary balls except for five doubtful cases where the dark particles could be an artificial contamination or a few spermatozoa remaining in the secretory ball. When a male copulates with an already mated female, his sperm would not be encapsulated in a secretory ball but would remain in the copulatory duct. Spermatozoa in a copulatory duct seem to be found more often in double-mated females. The assumption of first male sperm priority is supported by the copulatory behavior of the spiders. Females become distinctively reluctant to copulate a second time after their first copulation (Burger et al., 2006), which indicates that they become choosier with increasing copulation numbers, as suggested by Schäfer and Uhl (2002) for Pholcus phalangioides. However, more knowledge of female mating and oviposition histories is necessary to clarify a possible sperm priority pattern.

\section{Male Genital Organs and Cheliceral Modifications}

Male genital system. Assuming that there is no phenotypic variation in the traits we studied, the male genital system of Indicoblemma lannaianum consists of thick testes and thin convoluted vasa deferentia that lead into the unpaired ductus ejaculatorius. This organization is reported from most of all investigated spider families and seems to be general for spiders (e.g., Bertkau, 1875; Crome, 1951; Kim et al., 1993; Knoflach, 1998). The only exceptions known so far are theraphosid spiders, which show no external distinction between their convoluted testes and vasa deferentia (Melchers, 1964). In contrast to many other spider species, the testes of $I$. lannaianum seem to be very small and to possess only a low number of spermatid cysts (cf., Warren, 1928; Michalik et al., 2005b). In the male we investigated only a few spermatozoa are present in the ductus ejaculatorius, the place where the seminal fluid is accumulated. If this is the general state in males it further suggests that no sperm competition occurs within the female (see also Wedell et al., 2002). However, more studies are necessary to clar- 
ify this point. The ductus ejaculatorius is very wide and thus similar to the situation in Theridiidae (Knoflach, 1998; P.M., pers. obs.). It is filled with a huge amount of globular secretion that is obviously produced in the testes and the vasa deferentia since the epithelium of the ductus ejaculatorius is very flat.

Palpal bulb. The low amount of spermatozoa embedded in the huge mass of globular secretion in the palpal bulb is most evident and in striking contrast to the normal situation in spiders (e.g., Alberti, 1990). The sperm cells are irregularly distributed and it is most likely that males also transfer secretions besides the spermatozoa during copulation. The male secretions may be involved in the building of the secretory balls within the female's receptacula or they could play a role in sperm activation. Some components of the male secretions could afford nutriments to the spermatozoa, as proposed by Lopez (1987).

Chelicerae. As described by Burger et al. (2006), the male uses apophyses on his chelicerae to grasp grooves on the preanal plate of the female's opisthosoma, in this way building an efficient locking mechanism during copulation. The present study includes Figures 19 and 20, which illustrate that the apophyses are provided with fine lengthwise ridges that should enable an enhancement of the locking.

\section{Notes on the Spermatozoa}

As spermatozoa were only found in two of the seven available females prepared for TEM, only short notes can be given. In some respects the spermatozoa of Indicoblemma lannaianum that we studied are different compared with the present knowledge of spermatozoa of haplogynes and of spiders in general (see Rosati et al., 1970; Lopez and Boissin, 1976; Alberti and Weinmann, 1985; Alberti, 1990, 2000; Michalik et al., 2004b). The nucleus of the spermatozoa is elongated and seems to be coneshaped. The thin tube-like implantation fossa that extends into the nucleus from behind is filled with the dense centriolar adjunct, as also reported for other species (e.g., Alberti and Weinmann, 1985; Alberti, 1990; Michalik et al., 2003, 2004b, 2005b). Behind the centriolar adjunct, the centrioles are oriented in tandem position. It is remarkable that the spermatozoa of I. lannaianum possess only a very thin tube-like postcentriolar elongation of the nucleus, which is different from those of other species (e.g., Osaki, 1969; Alberti and Weinmann, 1985; Alberti et al., 1986; Alberti and Coyle, 1991; Michalik et al., 2004b).

\section{CONCLUSIONS}

The reproductive system of Indicoblemma lannaianum is characterized by several conspicuous features. The female genital system is astonishingly complex. The present study provides strong evidence for internal fertilization in this species, meaning in the uterus internus or the ovary. The definite function of the peculiar secretory balls remains mysterious. Sperm is encapsulated in discrete packages that very likely consist of male and female secretions. Sperm mixing of different males seems to be completely avoided, and in this way sperm competition may be efficiently prevented or at least severely limited. This mechanism may give females control over transferred sperm and enable them to favor the sperm of some males over others. Additional functions of the secretory balls could be to deliver a milieu suitable for the maintenance of the spermatozoa or "helping" the spermatozoa to find the small opening of the fertilization duct.

Males of Indicoblemma lannaianum produce only a small amount of spermatozoa. Hence, only a few spermatozoa are transferred, which further suggests that little or no sperm competition occurs within the female. The male secretions could be involved in the building of the secretory balls, play a role in sperm activation within the balls and the migration of the spermatozoa into the uterus internus, or they could provide nutrients to the spermatozoa.

Other tetrablemmid species seem to have similar complex genital systems (e.g., Bourne, 1980; Lehtinen, 1981; Burger, 2005). Further studies are needed in order to clarify the complex genital structures of tetrablemmids and to understand their function. Such studies may have an impact on the taxonomy of Tetrablemmidae and on our understanding of sexual selection and the evolution of genitalia in spiders (Eberhard, 1985, 1996, 2004a,b; Alberti, 1995; Uhl, 2002; Michalik et al., 2005a).

\section{ACKNOWLEDGMENTS}

We thank Peter Schwendinger, who discovered the investigated species and gave us important information about the type locality in Thailand. We also thank Gerd Alberti and Claus Wedekind for helpful comments.

\section{LITERATURE CITED}

Alberti G. 1990. Comparative spermatology of Araneae. Acta Zool Fenn 190:17-34.

Alberti G. 1995. Comparative spermatology of Chelicerata: review and perspective. In: Jamieson BGM, Ausio J, Justine J, editors. Advances in spermatozoal phylogeny and taxonomy, vol. 166. Mem Mus Natn Hist Nat Paris. p 203-230.

Alberti G. 2000. Chelicerata. In: Jamieson BGM, editor. Progress in male gamete ultrastructure and phylogeny. 8:311-388. In: Adiyodi KG, Adiyodi RG, editors. Reproductive biology of invertebrates. Oxford: IBH Publishing.

Alberti G, Coons LB. 1999. Acari: Mites. In: Harrison FW, Foelix RF, editors. Microscopic anatomy of invertebrates, vol. 8C. New York: Wiley-Liss. p 515-1215.

Alberti G, Coyle FA. 1991. Ultrastructure of the primary male genital system, spermatozoa, and spermiogenesis of Hypochilus pococki (Araneae, Hypochilidae). J Arachnol 19:136-149. 
Alberti G, Michalik P. 2004. Feinstrukturelle Aspekte der Fortpflanzungssysteme von Spinnentieren (Arachnida). Denisia 12: $1-62$.

Alberti G, Weinmann C. 1985. Fine structure of spermatozoa of some labidognath spiders (Filistatidae, Segestriidae, Dysderidae, Oonopidae, Scytodidae, Pholcidae; Araneae; Arachnida) with remarks on spermiogenesis. J Morphol 185:1-35.

Alberti G, Afzelius BA, Lucas SM. 1986. Ultrastructure of spermatozoa and spermatogenesis in bird spiders (Theraphosidae, Mygalomorphae, Araneae). J Submicrosc Cytol 18:739-753.

Austad SN. 1984. Evolution of sperm priority patterns in spiders. In: Smith RL, editor. Sperm competition and the evolution of animal mating systems. New York: Academic Press. p 223-249.

Berendonck B, Greven H. 2002. Morphology of female and male genitalia of Latrodectus revivensis Shulov, 1948 (Araneae, Theridiidae) with regard to sperm priority patterns. In: Toft S, Scharff N, editors. European arachnology 2000. Aarhus, Denmark: Aarhus University Press. p 157-167.

Berendonck B, Greven H. 2005. Genital structures in the entelegyne widow spider Latrodectus revivensis (Arachnida; Araneae; Theridiidae) indicate a low ability for cryptic female choice by sperm manipulation. J Morphol 263:118-132.

Bertani R, Silva PI Jr. 2002. The first mygalomorph spider without spermathecae: Sickius longibulbi, with a revalidation of Sickius (Araneae, Theraphosidae, Ischnocolinae). J Arachnol 30:519-526.

Bertkau P. 1875. Uber den Generationsapparat der Araneiden. Arch Naturgesch 41:235-262.

Bourne JD. 1980. New armored spiders of the family Tetrablemmidae from New Ireland and Northern India (Araneae). Rev Suisse Zool 87:301-317.

Brignoli PM. 1974. Tetrablemmidae (Araneae) dell' Angola e dello Zaire. Publcôes cult Co Diam Angola 88:177-196.

Brignoli PM. 1978. Some remarks on the relationships between the Haplogynae, the Semientelegynae and the Cribellatae (Araneae). Symp Zool Soc Lond 42:285-292.

Brown SG. 1985. Mating behavior of the golden orb-weaving spider, Nephila clavipes. II. Sperm capacitation, sperm competition, and fecundity. J Comp Psychol 99:167-175.

Burger M. 2005. The spider genus Indicoblemma Bourne, with description of a new species (Araneae: Tetrablemmidae). Bull Br Arachnol Soc 13:97-111.

Burger M, Nentwig W, Kropf C. 2003. Complex genital structures indicate cryptic female choice in a haplogyne spider (Arachnida, Araneae, Oonopidae, Gamasomorphinae). J Morphol 255:8093

Burger M, Jacob A, Kropf C. 2006. Copulatory behavior and web of Indicoblemma lannaianum from Thailand (Arachnida, Araneae, Tetrablemmidae). J Arachnol (in press).

Coddington JA, Levi HW. 1991. Systematics and evolution of spiders (Araneae). Annu Rev Ecol Syst 22:565-592.

Cooke JAL. 1966. Synopsis of the structure and function of the genitalia in Dysdera crocata (Araneae, Dysderidae). Senckenbergiana $47: 35-43$.

Coons LB, Alberti G. 1999. Acari: Ticks. In: Harrison FW, Foelix RF, editors. Microscopic anatomy of invertebrates, vol. 8C. New York: Wiley-Liss. p 267-514.

Coyle FA, Harrison FW, McGimsey WC, Palmer JM. 1983. Observations on the structure and function of spermathecae in haplogyne spiders. Trans Am Microsc Soc 102:272-280.

Crome W. 1951. Die grobe Morphologie des männlichen Genitalapparates einiger Araneen. Dtsch Zool Z 1:169-186.

DeCarvalho TN, Watson PJ, Field SA. 2004. Costs increase as ritualized fighting progresses within and between phases in the sierra dome spider, Neriene litigiosa. Anim Behav 68:473-482.

Deeleman-Reinhold CL. 1980. Contribution to the knowledge of the Southeast Asian spiders of the families Pacullidae and Tetrablemmidae. Zool Meded 56:65-82.

Eberhard WG. 1985. Sexual selection and animal genitalia. Cambridge, MA: Harvard University Press.

Eberhard WG. 1996. Female control: sexual selection by cryptic female choice. Princeton, NJ: Princeton University Press.
Eberhard WG. 2004a. Rapid divergent evolution of sexual morphology: comparative tests of antagonistic coevolution and traditional female choice. Evolution 58:1947-1970.

Eberhard WG. 2004b. Why study spider sex: special traits of spiders facilitate studies of sperm competition and cryptic female choice. J Arachnol 32:545-556.

Eberhard WG, Cordero C. 1995. Sexual selection by cryptic female choice on male seminal products - a new bridge between sexual selection and reproductive physiology. Trends Ecol Evol 10:493-496.

Eberhard WG, Guzmán-Gòmez S, Catley KM. 1993. Correlation between spermathecal morphology and mating systems in spiders. Biol J Linn Soc 50:197-209.

Elgar MA. 1998. Sperm competition and sexual selection in spiders and other arachnids. In: Birkhead TR, Møller AP, editors. Sperm competition and sexual selection. London: Academic Press. p 757-777.

Foelix RF. 1996. Biology of spiders, 2nd ed. New York: Oxford University Press.

Galis F. 1996. The application of functional morphology to evolutionary studies. Trends Ecol Evol 11:124-129.

Hellriegel B, Ward PI. 1998. Complex female reproductive tract morphology: its possible use in postcopulatory female choice. J Theor Biol 190:179-186.

Higgins LE. 1989. Effect of insemination on the morphology of the internal female genitalia of the spider Nephila clavipes (Araneae: Araneidae). Ann Entomol Soc Am 82:748-753.

Huber BA. 1993. Genital mechanics and sexual selection in the spider Nesticus cellulanus (Araneae: Nesticidae). Can J Zool 71:2437-2447.

Huber BA. 1994a. Genital morphology, copulatory mechanism and reproductive biology in Psilochorus simoni (Berland, 1911) (Pholcidae; Araneae). Neth J Zool 44:85-99.

Huber BA. 1994b. Copulatory mechanics in the funnel-web spiders Histopona torpida and Textrix denticulata (Agelenidae, Araneae). Acta Zool 75:379-384.

Huber BA. 1995. Copulatory mechanism in Holocnemus pluchei and Pholcus opilionoides, with notes on male cheliceral apophyses and stridulatory organs in Pholcidae (Araneae). Acta Zool 76:291-300.

Huber BA. 1997. On American Micromerys and Metagonia (Araneae, Pholcidae), with notes on behavior and natural history. Zool Scr 25:341-363.

Huber BA. 1998. Genital mechanics in some neotropical pholcid spiders (Araneae: Pholcidae), with implications for systematics. J Zool 244:587-599.

Huber BA. 2002. Functional morphology of the genitalia in the spider Spermophora senoculata (Pholcidae, Araneae). Zool Anz 241:105-116.

Huber BA. 2004a. Evolutionary transformation from muscular to hydraulic movements in spider (Arachnida, Araneae) genitalia: a study based on histological serial sections. J Morphol 261 364-376.

Huber BA. 2004b. Evidence for functional segregation in the directionally asymmetric male genitalia of the spider Metagonia mariguitarensis (González-Sponga) (Pholcidae: Araneae). J Zool Lond 262:317-326.

Huber BA, Eberhard WG. 1997. Courtship, copulation, and genital mechanics in Physocyclus globosus (Araneae, Pholcidae). Can J Zool 74:905-918.

Juberthie C, Lopez A, Kovoor J. 1981. Spermiogenesis and spermatophore in Telema tenella Simon (Araneae: Telemidae) — an ultrastructural study. Int J Invert Reprod 3:181-191.

Kaster JL, Jakob EM. 1997. Last-male sperm priority in a haplogyne spider (Araneae: Pholcidae): correlation between female morphology and patterns of sperm usage. Ann Ent Soc Am 90:254-259.

Kim JK, Kim TH, Moon MJ. 1993. Ultrastructure of the testis in the spider, Pardosa astrigera L. Koch. Korean Arachnol 9:4353

Knoflach B. 1998. Mating in Theridion varians Hahn and related species (Araneae: Theridiidae). J Nat Hist 32:545-604. 
Kovoor J. 1981. Une source probable de phéromone sexuelles: les glandes tégumentaires de la région genitale de femelles d'araignées. Atti Soc Toscana Sci Nat Mem B Suppl 88:1-15.

Lehtinen PT. 1981. Spiders of the Oriental-Australian region. III. Tetrablemmidae, with a world revision. Acta Zool Fenn 162:1151.

Lopez A. 1987. Glandular aspects of sexual biology. In: Nentwig W, editor. Ecophysiology of spiders. Berlin: Springer. p 121132.

Lopez A, Boissin L. 1976. La spermatide d'Holocnemus pluchei (Scop.) (Arachnida, Araneida, Pholcidae): Étude ultrastructurale. Bull Soc Zool France 101:423-431.

Melchers M. 1964. Zur Biologie der Vogelspinnen (Fam. Aviculariidae). Z Morph Oekol Tiere 52:517-536.

Michalik P, Gray MR, Alberti G. 2003. Ultrastructural observations of spermatozoa and spermiogenesis in Wandella orana Gray, 1994 (Araneae: Filistatidae) with notes on their phylogenetic implications. Tissue Cell 35:325-337.

Michalik P, Haupt J, Alberti G. 2004a. On the occurrence of coenospermia in mesothelid spiders (Araneae: Heptathelidae). Arthropod Struct Dev 33:173-181.

Michalik P, Dallai R, Giusti F, Alberti G. 2004b. The ultrastructure of the peculiar synspermia of some Dysderidae (Araneae, Arachnida). Tissue Cell 36:447-460.

Michalik P, Reiher W, Suhm-Tintelnot M, Coyle FA, Alberti G. 2005a. Female genital system of the folding-trapdoor spider Antrodiaetus unicolor (Hentz, 1842) (Antrodiaetidae, Araneae): ultrastructural study of form and function with notes on reproductive biology of spiders. J Morphol 263:284-309.

Michalik P, Sacher P, Alberti G. 2005b. Ultrastructural observations of spermatozoa of some tetragnathid spiders and their phylogenetic implications (Araneae, Tetragnathidae). J Morphol (in press).

Morishita R, Ferreira SA, Filha AS, Faraco CD. 2003. Studies on oogenesis and oviposition in the brown spider Loxosceles intermedia (Araneae: Sicariidae). Anat Rec 237A:575-582.

Noirot C, Quennedey A. 1991. Glands, gland cells, glandular units: some comments on terminology and classification. Ann Soc Entomol France 27:123-128.

Osaki H. 1969. Electron microscope study on the spermatozoon of the liphistiid spider Heptathela kimurai. Acta Arachnol Tokyo 22:1-12.

Platnick NI, Coddington JA, Forster RR, Griswold CE. 1991. Spinneret morphology and the phylogeny of haplogyne spiders. Am Mus Novit 3016:1-73.

Quennedey A. 1998. Insect epidermal gland cells: ultrastructure and morphogenesis. In: Harrison FW, Locke M, editors. Microscopic anatomy of invertebrates, vol. 11A. Insecta. New York: Wiley-Liss. p 177-207.

Rosati F, Baccetti B, Dallai R. 1970. The spermatozoon of Arthropoda. X. Araneids and the lowest Myriapods. In: Baccetti B, editor. Comparative spermatology. New York: Academic Press. p 247-254.

Schaefer D, Uhl G. 2003. Male competition over access to females in a spider with last-male sperm precedence. Ethology 109:385400.

Schäfer MA, Uhl G. 2002. Determinants of paternity success in the spider Pholcus phalangioides (Pholcidae: Araneae): the role of male and female mating behaviour. Behav Ecol Sociobiol 51:368-377.

Schwendinger PJ. 1989. On three new armoured spiders (Araneae: Tetrablemmidae, Pacullinae) from Indonesia and Thailand. Rev Suisse Zool 96:571-582.

Schwendinger PJ. 1994. Four new Perania (Araneae: Tetrablemmidae, Pacullinae) from Thailand and Malaysia. Rev Suisse Zool 101:447-464.

Senglet A. 2001. Copulatory mechanisms in Hoplopholcus, Stygopholcus (revalidated), Pholcus, Spermophora and Spermophorides (Araneae, Pholcidae), with additional faunistic and taxonomic data. Mitt Schweiz Ent Ges 74:43-67.

Senglet A. 2004. Copulatory mechanisms in Zelotes, Drassyllus and Trachyzelotes (Araneae, Gnaphosidae), with additional fau- nistic and taxonomic data on species from Southwest Europe. Mitt Schweiz Ent Ges 77:87-119.

Shear WA. 1978. Taxonomic notes on the armored spiders of the families Tetrablemmidae and Pacullidae. Am Mus Novit 2650: $1-46$.

Simon E. 1893. Histoire Naturelle des Araignées, 2ème ed., vol. I. Paris: Roret. p 257-488.

Suhm M, Alberti G. 1993. The fine structure of the spermatheca of Amaurobius fenestralis (Stroem, 1768) (Amaurobiidae, Araneae). Boll Acc Gioenia Sci Nat 26:343-353.

Suhm M, Alberti G. 1996. The fine structure of the spermatheca of Pardosa lugubris (Walckenaer, 1802). Rev Suisse Zool hors serie 635-642.

Suter RB, Parkhill VS. 1990. Fitness consequences of prolonged copulation in the bowl and doily spider. Behav Ecol Sociobiol 26:369-373.

Suzuki H. 1995. Fertilization occurs internally in the spider Achaearanea tepidariorum (C. Koch). Invertebr Reprod Dev 28:211-214.

Telford SR, Jennions MD. 1998. Establishing cryptic female choice in animals. Trends Ecol Evol 13:216-218.

Uhl G. 1994a. Genital morphology and sperm storage in Pholcus phalangioides (Fuesslin, 1775) (Pholcidae; Araneae). Acta Zool Stockh 75:1-12.

Uhl G. 1994b. Ultrastructure of the accessory glands in female genitalia of Pholcus phalangioides (Fuesslin, 1775) (Pholcidae; Araneae). Acta Zool Stockh 75:13-25.

Uhl G. 1996. Sperm storage secretion of female cellar spiders (Pholcus phalangioides; Araneae): a gel-electrophoretic analysis. J Zool 240:153-161.

Uhl G. 1998. Mating behaviour in the cellar spider, Pholcus phalangioides, indicates sperm mixing. Anim Behav 56:11551159.

Uhl G. 2000. Two distinctly different sperm storage organs in female Dysdera erythrina (Araneae: Dysderidae). Arthropod Struct Dev 29:163-169.

Uhl G. 2002. Female genital morphology and sperm priority patterns in spiders (Araneae). In: Toft S, Scharff N, editors. European arachnology 2000. Aarhus, Denmark: Aarhus University Press. p 145-156.

Uhl G, Gunnarsson B. 2001. Female genitalia in Pityohyphantes phrygianus, a spider with a skewed sex ratio. J Zool 255:367376.

Uhl G, Vollrath F. 1998. Genital morphology of Nephila edulis: implications for sperm competition in spiders. Can J Zool 76: $39-47$.

Uhl G, Huber BA, Rose W. 1995. Male pedipalp morphology and copulatory mechanism in Pholcus phalangioides (Fuesslin, 1775) (Araneae, Pholcidae). Bull Br Arachnol Soc 10:1-9.

Warren E. 1928. The comparative histology of the testis and the origin of the spermatozoa in certain South African spiders. Ann Natal Mus 6:1-88.

Watson PJ. 1991a. Multiple paternity and first mate sperm precedence in the sierra dome spider, Linyphia litigiosa Keyserling (Linyphiidae). Anim Behav 41:135-148.

Watson PJ. 1991b. Multiple paternity as genetic bet-hedging in female sierra dome spiders, Linyphia litigiosa (Linyphiidae). Anim Behav 41:343-360.

Wedell N, Gage MJG, Parker GA. 2002. Sperm competition, male prudence and sperm-limited females. Trends Ecol Evol 17:313320.

West HP, Toft S. 1999. Last-male sperm priority and the mating system of the haplogyne spider Tetragnatha extensa (Araneae: Tetragnathidae). J Insect Behav 12:433-450.

Wiehle H. 1967. Meta, - eine semientelegyne Gattung der Araneae (Arach.). Senckenbergiana 48:183-196.

Yoward PJ. 1998. Sperm competition in Pholcus phalangioides (Fuesslin, 1775) (Araneae, Pholcidae) - shorter copulations gain higher paternity reward than first copulations. Proc 17th Eur Coll Arach, Edinburgh 1997:167-170. 